\title{
On Protomerulius and Heterochaetella (Auriculariales, Basidiomycota)
}

\author{
Viacheslav Spirin ${ }^{1,2}\left(\mathbb{D} \cdot\right.$ Vera Malysheva $^{3} \cdot$ Otto Miettinen $^{1} \cdot$ Josef Vlasák ${ }^{4} \cdot$ Renato Lúcio Mendes Alvarenga $^{5}$. \\ Tatiana Baptista Gibertoni ${ }^{5} \cdot$ Leif Ryvarden $^{6} \cdot$ Karl-Henrik Larsson ${ }^{2}$
}

Received: 3 June 2019 / Revised: 16 July 2019 / Accepted: 23 July 2019

(C) The Author(s) 2019

\begin{abstract}
The taxonomy of Protomerulius and Heterochaetella is revised based on DNA data and morphological evidence, and their type species, P. brasiliensis and H. dubia, are proved to be congeneric. As a consequence, H. dubia and related species, of which four are described as new, are placed in Protomerulius. Heterochaete microspora is also combined in Protomerulius, and the genus concept is redefined to encompass effused species with smooth or spiny hymenophore and monomitic hyphal structure. Psilochaete multifora, gen. and spec. nov. is a distant relative of Protomerulius spp. found in Norway. Heterochaetella cystidiophora is re-collected in Brazil and placed in the synonyms of Heterochaete sanctae-catharinae. This species does not belong to the Protomerulius-Heterochaetella lineage, and it is transferred to Metulochaete, gen. nov.
\end{abstract}

Keywords Heterobasidiomycetes $\cdot$ Phylogeny $\cdot$ Polypores $\cdot$ Taxonomy $\cdot$ New taxa

\section{Introduction}

Protomerulis brasiliensis Möller was described from Brazil as a poroid fungus with septate basidia (Möller 1895). This was the first record of a species with poroid hymenophore among the so-called jelly fungi (heterobasidiomycetes). Both the genus and the species remained almost forgotten until

Responsible editor: Yu-Cheng Dai

Viacheslav Spirin

viacheslav.spirin@helsinki.fi

1 Finnish Museum of Natural History, University of Helsinki, PO Box 7, 00014 Helsinki, Finland

2 Natural History Museum, University of Oslo, P.O. Box 1172, Blindern, 0318 Oslo, Norway

3 Komarov Botanical Institute, Russian Academy of Sciences, Prof. Popova str. 2, 197376 St., Petersburg, Russia

4 Biology Centre, Academy of Sciences of the Czech Republic, Branišovská 31, 37005 České Budějovice, Czech Republic

5 Departamento de Micologia, Centro de Biociências, Universidade Federal de Pernambuco, Av. da Engenharia s/n,

Recife, Pernambuco 50740-570, Brazil

6 Department of Biosciences, University of Oslo, P.O. Box 1066, Blindern, 0316 Oslo, Norway
Friedrichsen (1977) published a list of Möller's collections preserved at the herbarium in Hamburg. Afterwards, Bandoni et al. (1982) studied one of the authentic collections labelled as $P$. brasiliensis and published a detailed description as well as microscopic drawings. Because Protomerulius is much older than other generic names for poroid heterobasidiomycetes (i.e., Elmerina Bres., Aporpium Bondartsev \& Singer and Protodaedalea Imazeki), the resurrection of Protomerulius caused a lot of discussion concerning generic rearrangement of the group (Setliff \& Ryvarden 1982, Ryvarden 1991, Reid 1992). However, no satisfactory solution for splitting this complex was proposed.

Weiss and Oberwinkler (2001) included some modern collections of Protomerulius spp. in the phylogenetic study of the Auriculariales. According to their results, Protomerulius forms a strongly supported clade together with corticioid (Heterochaetella brachyspora Luck-Allen), hydnoid (Protohydnum piceicola Kühner), and clavarioid (Tremellodendropsis sp.) taxa, and it is not closely related to the other poroid representatives of the order. While the latter ones (i.e., Aporpium, Elmerina, and Protodaedalea), as well as Protohydnum were rather extensively studied in the last years (Miettinen et al. 2012, Zhou \& Dai 2013, Sotome et al. 2014, Vlasák et al. 2016, Malysheva et al. 2018), only a few new sequences were generated for Protomerulius and Heterochaetella, and therefore, their relationships stayed 
unresolved. In the present study, we revise generic and species-level taxonomy of Protomerulius and associated taxa, and provide new information about Heterochaetella cystidiophora Lowy.

\section{Material and methods}

Morphological study Type specimens and collections from herbaria BO, BPI, CWU, GB, H, HBG, K, LE, MAN, NY, $\mathrm{O}, \mathrm{PC}$, TAAM, TRTC, URM, as well as from the private herbarium of author JV were studied. Herbarium acronyms are given according to Thiers (2019). Microscopic routine follows Miettinen et al. (2018). All measurements were made from microscopic slides mounted in Cotton Blue, using phase contrast and oil immersion lens (Leitz Diaplan microscope, $\times$ 1250 amplification). The following abbreviations are used in morphological descriptions and species key for Protomerulius spp.: $L$, basidiospore length; $W$, basidiospore width; $Q$, length/width ratio; $Q$, length/width ratio; $n$, number of measurements per specimens measured.

Molecular techniques In total, 44 specimens were selected for molecular sampling (Table 1). For most specimens, DNA was extracted from small fragments of dried basidiocarps using the NucleoSpin Plant II Kit (Macherey-Nagel GmbH \& Co. KG) according to the manufacturer's protocols. The following primers were used for amplification and sequencing: ITS1F-ITS4 (White et al. 1990; Gardes \& Bruns 1993) for the ITS1-5.8S-ITS2 fragment; JS1-LR5 (Vilgalys \& Hester 1990; Landvik 1996) for part of nrLSU region; EF1-983F and EF1-1567R for approximately 500-600 bp of tefl (Rehner \& Buckley 2005). PCR products were purified applying the GeneJET Gel Extraction Kit (Thermo Scientific, Thermo Fisher Scientific Inc., MA, USA). Sequencing was performed with an ABI model 3130 Genetic Analyzer (Applied Biosystems, CA, USA). Raw data were edited and assembled in MEGA X (Kumar et al. 2018). Molecular studies of some specimens were carried out at the center for collective use of scientific equipment "Cellular and molecular technology of studying plants and fungi" (Komarov Botanical Institute, Russian Academy of Sciences, St. Petersburg), and a few poroid specimens were sequenced as described in Miettinen et al. (2018).

Phylogenetic analyses For this study, 35 nrITS, 30 nrLSU, and 11 tefl sequences were generated (Table 1). In addition to the newly generated sequences, $47 \mathrm{nrITS}$ and $45 \mathrm{nrLSU}$ were retrieved from the GenBank database (www.ncbi.nlm.nih. gov/genbank/). Sequences were aligned with the MAFFT version 7 Web tool (http://mafft.cbrc.jp/alignment/server/) using the Q-INS-i option for nrITS and nrITS+nrLSU datasets.

Phylogenetic reconstructions were performed with maximum likelihood (ML) and Bayesian inference (BI) analyses. Before the analyses, the best-fit substitution model was estimated separately for all alignments based on the Akaike information criterion (AIC) using FindModel Web server (http://www.hiv.lanl.gov/content/sequence/ findmodel/findmodel.html). GTR model was chosen for all datasets. ML analysis was run on RAxML server, v.0. 6.0 (http://raxml-ng.vital-it.ch/\#/) with one hundred rapid bootstrap replicates. BI analysis was performed with MrBayes 3.2.5 software (Ronquist et al. 2012), for two independent runs, each with 5 million generations for concatenated dataset (nrITS+nrLSU) and 10 million generations for nrITS and tefl datasets, under described model and four chains with sampling every 100 generations. To check for convergence of MCMC analyses and to get estimates of the posterior distribution of parameter values, Tracer v1.7.1 was used (Rambaut et al. 2018). We accepted the result where the ESS (effective sample size) was above 200 and the PSRF (potential scale reduction factor) was close to 1 . Newly generated sequences have been deposited in GenBank with corresponding accession numbers (Table 1). The alignments have been deposited in TreeBASE (S23966, S23967).

\section{Results}

Three datasets were prepared for the present study: (1) nrITS + nrLSU dataset used to reconstruct a general topology of the Auriculariales, with special emphasis on Protomerulius and Heterochaetella spp., (2) nrITS and (3) tefl datasets supporting species concepts in the genus Protomerulius as redefined below.

1. nrITS + nrLSU dataset. The final alignment contained 1646 characters (including gaps). The overall topologies of the ML and BI trees were nearly identical and confirmed that Protomerulius and most Heterochaetella spp. (including the genus type, Heterochaetella dubia (Bourdot \& Galzin) Bourdot \& Galzin) belong to one strongly supported clade, while $H$. cystidiophora and a still unnamed taxon with a certain morphological similarity to the $\mathrm{H}$. dubia complex form their own lineages within the order (Fig. 1).

A) Protomerulius/Heterochaetella lineage $(\mathrm{pp}=1, \mathrm{bs}=$ 95 ) is uncovered as a sister clade of Hyalodon V. Malysheva \& Spirin (typified with Protohydnum piceicola Kuehner ex Bourdot). This outcome agrees with the earlier studies of the Auriculariales (Weiss 
Table 1 DNA sequences generated for the present study

\begin{tabular}{|c|c|c|c|c|c|c|}
\hline \multirow[t]{2}{*}{ Species } & \multirow{2}{*}{$\begin{array}{l}\text { Specimen/ } \\
\text { herbarium }\end{array}$} & \multirow{2}{*}{$\begin{array}{l}\text { Place of origin } \\
\text { (ISO code) }\end{array}$} & \multirow[t]{2}{*}{ Host } & \multicolumn{3}{|c|}{ GenBank number } \\
\hline & & & & $\operatorname{nrLSU}$ & nrITS & tef1 \\
\hline Metulochaete sanctae-catharinae & AM 0678 (URC) & BR-AC & Hardwood & MK480575 & MK484065 & - \\
\hline Protomerulius brachysporus & PV $2600(\mathrm{H})$ & FI & Picea abies & MK480547 & MK484033 & MK497236 \\
\hline P. brachysporus & LR $23195(\mathrm{O})$ & MX & Conifer & MK480548 & MK484038 & - \\
\hline P. brachysporus & O F293193 & NO & P. abies & MK480550 & MK484036 & - \\
\hline P. brachysporus & TAAM 102746 & RU-PRI & Abies nephrolepis & - & MK484037 & - \\
\hline P. brachysporus & JN $7643(\mathrm{O})$ & SE & P. abies & - & MK484035 & - \\
\hline P. brachysporus & VS 8351c $(H)$ & USA-WA & Thuja plicata & MK480549 & MK484034 & - \\
\hline Protomerulius commotus & VS $11097(O)$ & NO & Ulmus glabra & MK480552 & MK484039 & MK497237 \\
\hline P. commotus & VS $11110(\mathrm{O})$ & NO & U. glabra & MK480551 & MK484040 & - \\
\hline Protomerulius dubius & RS $14396(\mathrm{H})$ & FI & Alnus glutinosa & - & MK484042 & - \\
\hline P. dubius & VS $3019(\mathrm{H})$ & RU-NIZ & Populus tremula & MK480553 & MK484041 & - \\
\hline Protomerulius hebes & LR $28406(\mathrm{O})$ & ET & Hardwood & MK480554 & - & - \\
\hline Protomerulius madidus & VS $9845(H)$ & $\mathrm{EE}$ & Fraxinus excelsior & MK480555 & - & MK497238 \\
\hline P. madidus & KHL $17664(\mathrm{O})$ & NO & Rotten wood & MK480559 & MK484047 & - \\
\hline P. madidus & VS $11045(\mathrm{O})$ & NO & Alnus incana & MK480563 & MK484049 & MK497241 \\
\hline P. madidus & VS $11053(\mathrm{O})$ & NO & Betula pubescens & - & MK484053 & MK497244 \\
\hline P. madidus & VS $11094(\mathrm{O})$ & NO & U. glabra & - & MK484052 & MK497243 \\
\hline P. madidus & VS $11102(\mathrm{O})$ & NO & U. glabra & MK480556 & MK484043 & \\
\hline P. madidus & VS $11108(O)$ & NO & U. glabra & MK480562 & MK484048 & \\
\hline P. madidus & VS $11588(O)$ & NO & U. glabra & MK480558 & MK484045 & \\
\hline P. madidus & VS $11641(\mathrm{O})$ & NO & A. incana & MK480557 & MK484044 & MK497239 \\
\hline P. madidus & VS $11671(O)$ & NO & U. glabra & MK480560 & MK484046 & MK497240 \\
\hline P. madidus & VS $12425(\mathrm{O})$ & NO & F. excelsior & - & MK484051 & - \\
\hline P. madidus & VS $12492(\mathrm{O})$ & NO & U. glabra & - & MK484050 & MK497242 \\
\hline P. madidus & CWU 5998 & UA & A. glutinosa & MK480561 & MK484054 & - \\
\hline Protomerulius microsporus & LR $23440(\mathrm{O})$ & $\mathrm{MX}$ & Hardwood & MK480564 & MK484055 & - \\
\hline Protomerulius minor & KHL 15937 (O) & BR-PE & Hardwood & MK480569 & MK484060 & - \\
\hline P. minor & OM $15492(\mathrm{H})$ & US-NY & Hardwood & MK480566 & MK484057 & - \\
\hline P. minor & OM $15700(\mathrm{H})$ & US-NY & Acer? & MK480567 & MK484058 & - \\
\hline P. minor & OM $17461(\mathrm{H})$ & US-AR & Hardwood & MK480568 & MK484059 & - \\
\hline P. minor & OM $19586(\mathrm{H})$ & US-NC & Tilia americana & MK480565 & MK484056 & MK497245 \\
\hline Protomerulius pertusus & O F75913 & NO & U. glabra & MK480570 & MK484063 & - \\
\hline P. pertusus & KHL 17572 (O) & NO & Rotten wood & MK480573 & MK484061 & - \\
\hline P. pertusus & VS $3081(H)$ & RU-NIZ & Quercus robur & MK480574 & MK484062 & - \\
\hline P. pertusus & VS $3149(\mathrm{H})$ & RU-NIZ & Q. robur & MK480572 & - & - \\
\hline P. pertusus & VS $11947(\mathrm{H})$ & RU-NIZ & Corylus avellana & MK480571 & MK484064 & - \\
\hline Protomerulius subreflexus & OM $5642(\mathrm{H})$ & ID & Hardwood & - & MK636543 & - \\
\hline P. subreflexus & OM $13695(\mathrm{H})$ & ID & Hardwood & - & MK636542 & - \\
\hline P. subreflexus & OM $14402(\mathrm{H})$ & ID & Hardwood & MG757508 & MG757508 & MK649813 \\
\hline P. substuppeus & JV 1407/104 (H) & $\mathrm{CR}$ & Hardwood & - & MK434169 & - \\
\hline P. substuppeus & LR $41683(\mathrm{O})$ & $\mathrm{JM}$ & Dead wood & - & MK636539 & - \\
\hline P. substuppeus & LR $39093(\mathrm{O})$ & PR & Hardwood & - & MK636541 & - \\
\hline P. substuppeus & Ipulet F483 (O) & UG & Rotten wood & - & MK636540 & - \\
\hline Psilochaete multifora & VS $11596(\mathrm{O})$ & NO & U. glabra & MK480576 & MK484066 & MK497246 \\
\hline
\end{tabular}


\& Oberwinkler 2001, Zhou \& Dai 2013, Malysheva et al. 2018). Two poroid species with effusedreflexed basidiocaprs, Protomerulius substuppeus (Berk. \& Cooke) Ryvarden (= P. brasiliensis, the generic type-see below) and P. subreflexus (Lloyd) Miettinen \& Ryvarden are nested in a strongly supported subclade ( $\mathrm{pp}=1$, bs $=100$ ) together with the effused, hydnoid species Heterochaete microspora Burt. Remaining sequences that were recovered in the Protomerulius/Heterochaetella clade were obtained from effused, smooth, or hydnoid specimens corresponding to the current concept of Heterochaetella dubia (as understood by Reid 1990 and Roberts 1998).

These sequences form seven clades interpreted as separate species. Macroscopically, the two poroid Protomerulius species look strikingly different from the effused, smooth, or hydnoid taxa (Fig. 4). However, retaining Protomerulius for poroid taxa only is not possible because at least the hydnoid $H$. microspora should have been included in the genus so redefined. Alternatively, to keep polypores separate, at least four new, morphologically indistinguishable genera should be created, placing $P$. subreflexus and $P$. substuppeus to different genera, which we do not consider a practical solution. Therefore, we consider the whole Protomerulius/ Heterochaetella clade as one genus for which Protomerulius is the oldest available name. Morphological evidences for this solution are discussed in the taxonomic part of this paper.

B) An unnamed taxon with effused, smooth basidiocarps clusters with Hyalodon and Protomerulius (incl. Heterochaetella) but with low support $(\mathrm{pp}=0.92, \mathrm{bs}=$ 65). Considering its clear morphological differences from the two latter genera, it is introduced below as Psilochaete multifora, gen. and sp. nov.

C) Heterochaetella cystidiophora Lowy is not related to the previous taxa and detected among the "core" Auriculariales genera (e.g., Auricularia, Exidia, Exidiopsis, etc.) although it is clearly isolated from them. This result agrees with morphological data because the only similarity shared by $H$. cystidiophora with some members of Heterochaetella dubia complex is a hydnoid hymenophore while all essential microscopic characters (hyphal structure, shape, and size of basidia and basidiospores) are widely different. In our opinion, $H$. cystidiophora is a younger synonym of Heterochaete sanctae-catharinae Möller (see "Taxonomy" section). No older generic names are available for it, and therefore, it is placed in a new genus, Metulochaete.
2. nrITS dataset. The final alignment contained 692 characters (including gaps). The overall topologies of the ML and BI trees were nearly identical and corresponded to nrITS + nrLSU phylogeny of Protomerulius (incl. Heterochaetella) although with a much broader set of sequences (Fig. 2).

3. tefl dataset. The final alignment contained 600 characters (including gaps). The topology reveals no contradictions against nrITS + nr LSU and nrITS phylogenies albeit tef1 sequences were available for five Protomerulius species only (Fig. 3).

Here, we present our taxonomic conclusions, with taxa treated in alphabetical order. Taxonomic changes proposed in the present paper are summarized in Table 2.

\section{Taxonomy}

Metulochaete Alvarenga, gen. nov. MB 830966

Etymology. Metulochaete (Lat., noun) — the name refers to metuloid cystidia covering hymenophoral spines.

Basidiocarps effused, continuous, pale-colored, gelatinous to waxy-arid, smooth or covered by sterile spines. Hyphal structure monomitic; hyphae clamped, hyaline. Hyphidia present, branched. Cystidia metuloid, covering hymenial spines. Basidia 4-celled, sessile, ovoid. Basidiospores thin-walled, allantoid, straight to slightly curved. On wood remnants.

Type species. Heterochaete sanctae-catharinae Möller.

Effused basidiocarps and sterile spines densely distributed on the hymenial surface make Heterochaete sanctaecatharinae (= Heterochaetella cystidiophora) similar to Heterochaete s.l. However, the latter genus is polyphyletic (Malysheva \& Spirin 2017, Alvarenga et al. 2019), and no other species addressed to it possess heavily encrusted, thick-walled (metuloid) cystidia covering sterile hymenial outgrowths.

Metulochaete sanctae-catharinae (Möller) Alvarenga, comb. nov.-Fig. 5.

MB 830967

$\equiv$ Heterochaete sanctae-catharinae Möller, Bot. Mitth. Tropen 8: 81, 1895. Lectotype. Table 4, Fig. 8 in A. Möller, Bot. Mitth. Tropen 8, 1895 (selected here, MBT 387039).

= Heterochaetalla cystidiophora Lowy, Flora Neotropica 6: 82, 1971.

Basidiocarps effused, orbicular or fusing together, continuous, yellowish-white, gelatinous when fresh, waxy-arid when dried, smooth or covered by more or less regularly distributed, rather blunt spines $125-150 \times 35-45 \mu \mathrm{m}, 7-8$ per 
hymenial surface smooth or nearly smooth hymenial surface hydnoid

hymenial surface poroid

0.99/94 [ Protodontia subgelatinosa VS 11038 $1 / 100$ Protodontia subgelatinosa OM 13489 Protodontia insularis LR 49417 Ofella glaira VS 11809

Stypellopsis farlowii KHL12337

Stypellopsis hyperborea VS 11066 P. multifora VS 11596

Psilochaete

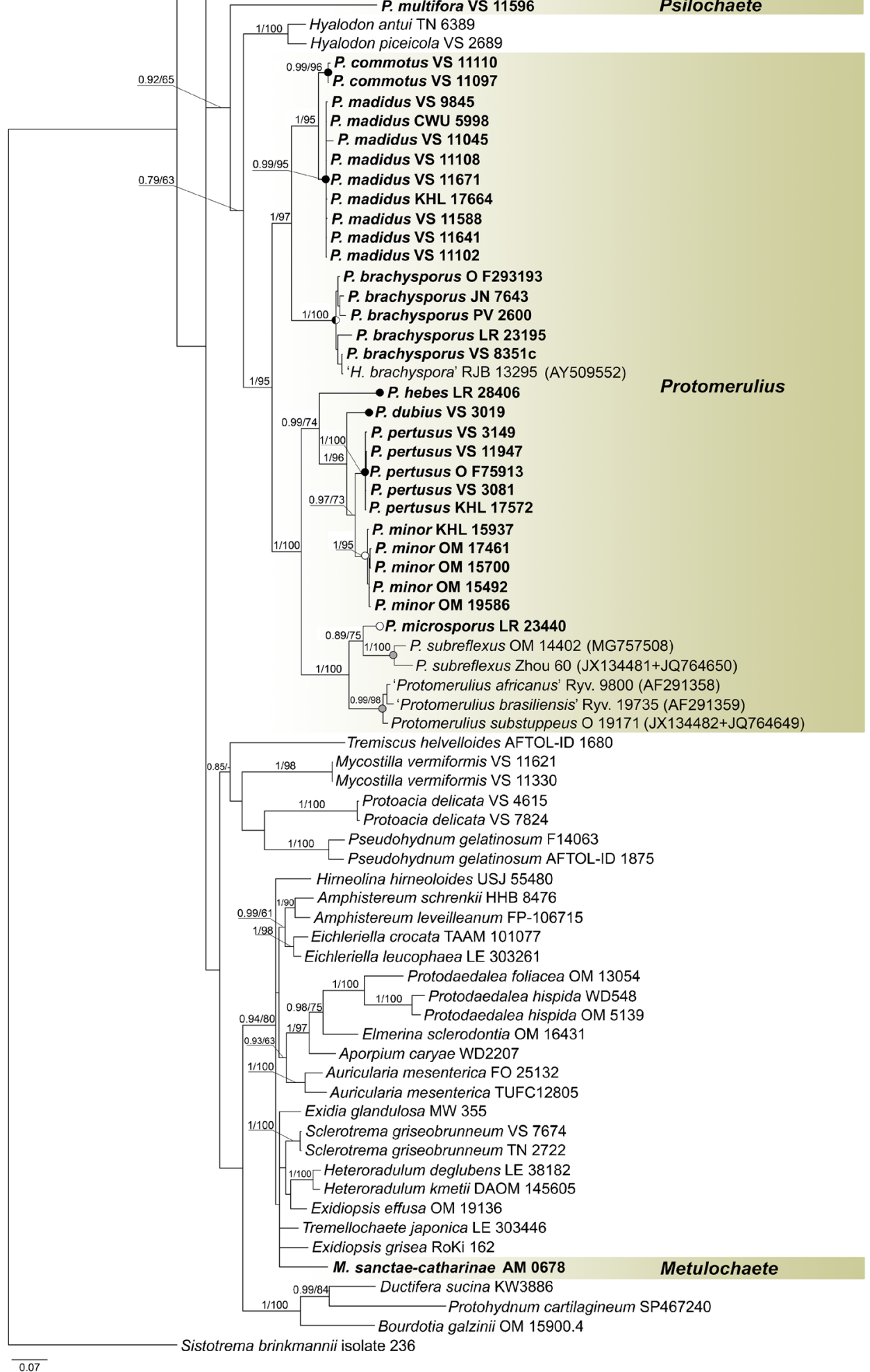

Fig. 1 Combined phylogenetic nrITS+nrLSU topology from Bayesian inference analysis showing main lineages within Auriculariales. All sequences generated for this study are indicated in bold faces. Collection numbers are given for all sequences. Support values (BA/
ML) are given above the branches. Scale bar shows expected changes per site. Original names are retained for the sequences obtained in GenBank (given in inverted commas) 
Fig. 2 Best tree from maximum likelihood analysis for the nrITS dataset showing phylogenetic relationships of Protomerulius species. All sequences generated for this study are indicated in bold faces. Collection numbers are given for all sequences. Support values (ML/BA) are given on the branches. Scale bar shows expected changes per site. Original names are retained for the sequences obtained in GenBank (given in inverted commas)

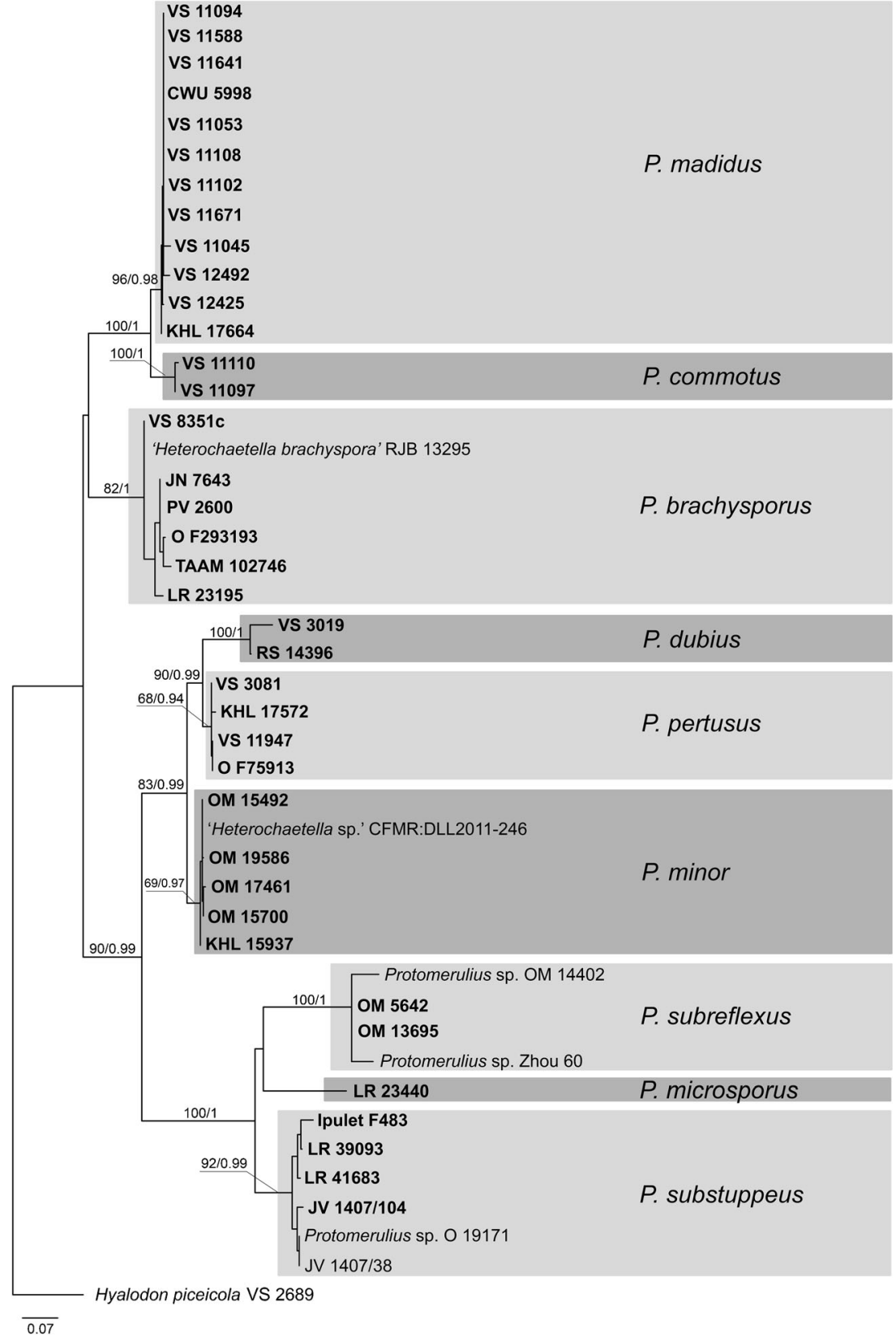

$\mathrm{mm}$, margin adnate, compact, white or very pale creamcolored.

Hyphal structure monomitic; hyphae clamped, hyaline, slightly thick-walled and 2-4 $\mu \mathrm{m}$ in diam. in subiculum, thin-walled and 1.5-2 $\mu \mathrm{m}$ in diam. in subhymenium. Hyphidia present, branched, 1-2 $\mu \mathrm{m}$ in diam. at the apex. Cystidia heavily encrusted, sharp, ventricose, thick-walled, 15-20 × 5-8.5 $\mu \mathrm{m}$, covering hymenial spines. Basidia 4celled, sessile, ovoid, 17-20×11-14 $\mu \mathrm{m}$. Basidiospores thin-walled, allantoid, straight to slightly curved, (10.1-) 11.5-15.6 (-16.2) × (4.5-) 4.7-6.4 (-7.1) $\mu \mathrm{m}(n=46 / 2), \mathrm{L}=$ $14.06-14.23, \mathrm{~W}=5.14-5.80, \mathrm{Q}=2.42-2.76$.
Distribution and ecology. Brazil (Acre, Santa Catarina); on wood remnants of angiosperms.

Remarks. Möller (1895) described and illustrated Heterochaete sanctae-catharinae based on specimens from southern Brazil (Blumenau-Santa Catarina). After almost eight decades, Lowy (1971) studied specimens with sterile spines covered by metuloid cystidia from the same area of Brazil and introduced them as a new species, Heterochaetella cystidiophora. In our opinion, the description and illustration of $H$. sanctae-catharinae indicate that it is identical with Heterochaetella cystidiophora. Friedrichsen (1977) mentioned an authentic specimen of $H$. sanctae- 


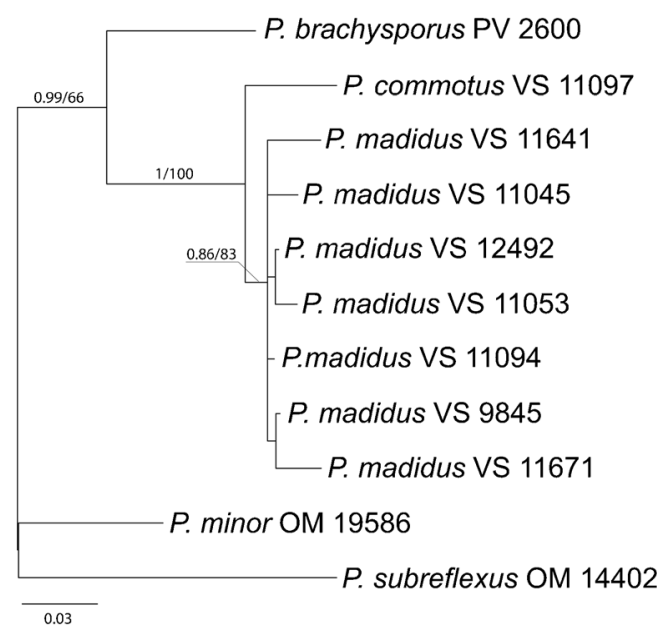

Fig. 3 Midpoint Bayesian phylogram for the tefl dataset showing major lineages of the Protomerulius. Collection numbers are given for all sequences. Support values (BA/ML) are given on the branches. Scale bar shows expected changes per site

catharinae stored in HBG. However, the author VS was unable to find it there. Therefore, the species is typified here with Möller's illustration.

In the protologue, $H$. cystidiophora was introduced as lacking clamps. Roberts (1998) studied the type specimen and found regular clamp connections. This agrees with our observations. Roberts moved $H$. cystidiophora to the artificial genus Heterochaete, and the same combination was proposed a few months earlier by Kisimova-Horovitz et al. (1997). The latter authors reported H. cystidiophora from Costa Rica. Judging from their spore measurements, the Costa Rican collections may well represent another species of Metulochaete.

Protomerulius Möller, Bot. Mitth. Tropen 8: 129, 1895.

Basidiocarps annual, resupinate to effused-reflexed or rarely sessile-pileate, smooth or irregularly warted to hydnoid or regularly poroid, soft, waxy-gelatinized to floccose. Hyphal structure mono- or dimitic; skeletal hyphae thick-walled, normally with a rather wide lumen, CB $(+)$, generative hyphae clamped. Thick-walled tramal cystidia present in effused species, deeply rooted, often in fascicles. Hyphidia present. Gloeocystidia and hymenial cystidia occurring in some species. Rosettelike or stellate crystals present among hyphae or on sterile hymenial cells. Basidia (2-) 4-celled, stipitate, with rather short and thick sterigmata. Basidiospores thin-walled (although the spore wall distinct), broadly cylindrical to subglobose, 4-9.5 × 3-6 $\mu \mathrm{m}$, repetitive. On various wood remnants.

Type species. Protomerulius brasiliensis Möller.

The genus is redefined here to embrace two poroid species (P. subreflexus and P. substuppeus), Heterochaete microspora and members of the Heterochaetella dubia complex. Despite dissimilar macroscopic habit of poroid and hydnoid/smooth taxa included in Protomerulius in this study, they share several important anatomical features. First, basidia of all aforementioned taxa are sphaeropedunculate, i.e., divided in a more or less globose, two- or four-celled apical part and a pronounced stalk. Basidia of this kind were detected in several other genera of the Auriculariales (Spirin et al., 2019a, b); however, none of them possesses long, thick-walled, fasciculate tramal cystidia as occurring in effused, non-poroid members of Protomerulius. Those cystidia are evidently homologous to skeletal hyphae of the poroid Protomerulius spp., which originate deep in tube trama and enter in dissepiment edges as slightly swollen and almost thin-walled emergences. In this respect, $P$. microsporus and $P$. minor represent a transitional case - they both are effused, hydnoid species but their tramal cystidia are not well-differentiated and can be interpreted as thin-walled apices of skeletal hyphae. Stellate crystals occurring among hyphae and sometimes encrusting hymenial cells were found in all Protomerulius species treated below; therefore, their presence is another morphological feature of the genus.

The closely related genus Hyalodon differs from Protomerulius in having poorly developed subiculum and distinctly hydnoid, gelatinized hymenophore. Tramal hyphae of Hyalodon spp. are more or less strictly parallel, tightly arranged and often densely encrusted by angular crystals (Malysheva et al. 2018). These features as well as absence of cystidia differentiate Hyalodon spp. from Protomerulius.

Table 2 Taxonomic changes proposed in the present study

Taxonomic names in the Protomerulius-Heterochaetella complex as presented in the literature (fide Luck-Allen 1961,

Lowy 1971 and Ryvarden 1991)
Heterochaetella brachyspora Luck-Allen

H. cystidiophora Lowy

H. dubia (Bourdot \& Galzin) Bourdot \& Galzin

Protomerulis brasiliensis A. Möller

Stypella minor Möller
Accepted in the present study as

Protomerulius brachysporus (Luck-Allen) Spirin \& V. Malysheva

Metulochaete sanctae-catharinae (Möller) Alvarenga

Protomerulius dubius (Bourdot \& Galzin) Spirin \& V. Malysheva

P. substuppeus (Berk. \& Cooke) Ryvarden

P. minor (Möller) Spirin \& Miettinen 

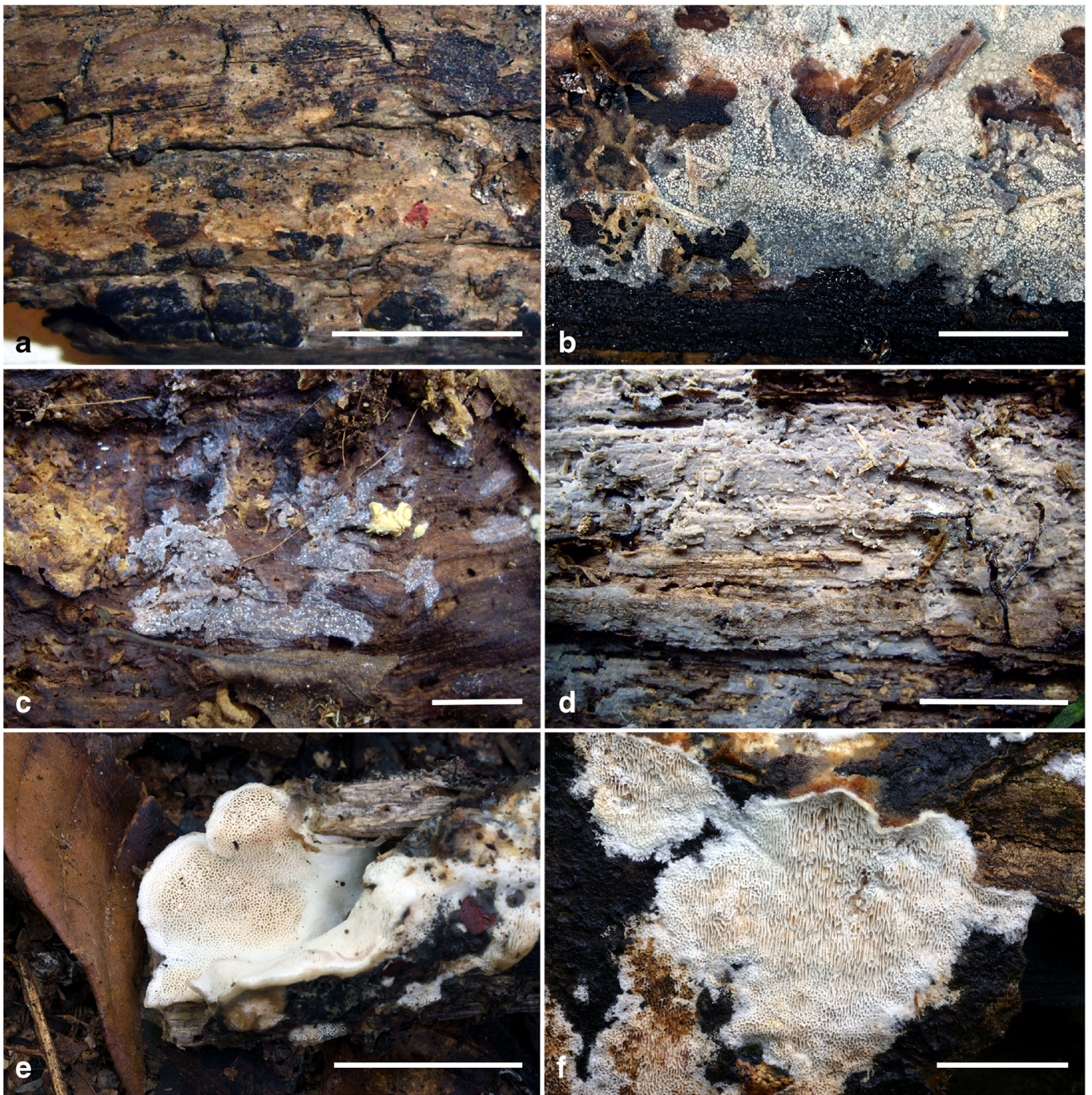

Fig. 4 Basidiocarps of Protomerulius spp.: a P. brachysporus (isotype); b P. minor (Miettinen 15700); c P. madidus (Spirin 11588, senescent basidiocarp with characteristic white inclusions); d P. madidus (holotype); e P. subreflexus (Miettinen 14392); f P. substuppeus (Vlasák 0409/10). Scale bar = 10 mm

Protomerulius brachysporus (Luck-Allen) Spirin \& V. Malysheva, comb. nov.-Figs. 4a, 6b-d, and 7.

MB 830953

$\equiv$ Heterochaetella brachyspora Luck-Allen, Canadian J. Bot. 38: 566, 1960. Holotype. France: Var, Toulon, on wood in a dike, VI.1925 Crozalc 70 (herb. Bourdot 39164) (PCisotype, studied).

= Heterochaetella dubia f. crassior Bourdot \& Galzin, Hymén. France: 52, 1928. Lectotype. France. Aveyron: Causse Noir, Pinus sp., XII.1910 Galzin 7858 (herb. Bourdot 7606) (PC, studied) (selected here, MBT 387040).

$=$ Heterochaetella dubia f. sphaerospora Bourdot \& Galzin, Hymén. France: 52, 1928. Lectotype. France. Aveyron: Causse Noir, Pinus sp., 20.XI.1913 Galzin 14489 (herb. Bourdot 14496) (PC, studied) (selected here, MBT 387041).

Basidiocarps effused, first smooth or covered by minute, irregularly arranged warts, floccose, reticulate, white or greyish, with craters or holes, then continuous, greyish or ochraceous, waxy, old basidiocarps brownish, strongly gelatinized, some producing irregularly distributed spine-like outgrowths, up to $5 \mathrm{~cm}$ in widest dimension, $0.05-0.5$ (1) $\mathrm{mm}$ thick, margin narrow, pruinose, whitish to cream-colored.

Hyphal structure monomitic or occasionally dimitic; skeletal hyphae occurring in subiculum of mature specimens, hyaline to brownish, distinctly thick-walled, $1.8-2.5 \mu \mathrm{m}$ in diam., generative hyphae dominating, clamped, thin- or only slightly thick-walled, 1.5-3 (3.5) $\mu \mathrm{m}$ in diam., occasionally 


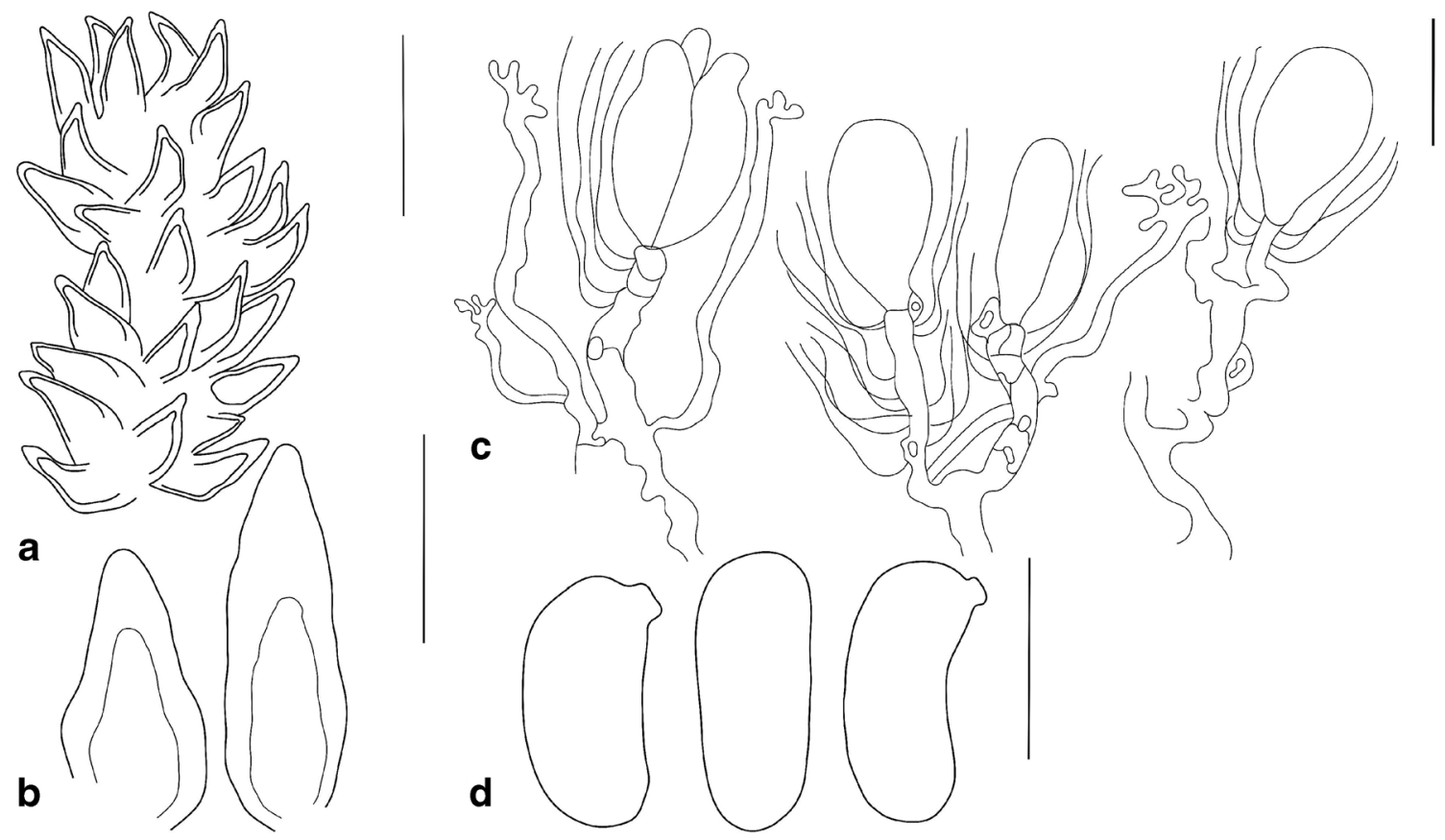

Fig. 5 Metulochaete sanctae-catharinae (URM 93055): a hymenial spine covered by cystidia; b separate cystidia; c subhymenial hyphae and basidia; d basidiospores. Scale bar, $\mathbf{a}=50 \mu \mathrm{m}, \mathbf{b}-\mathbf{d}=10 \mu \mathrm{m}$

inflated up to $4.5 \mu \mathrm{m}$ in diam. in subiculum. Tramal cystidia abundant, hyaline to brownish, tubular-clavate, flexuous, slightly or moderately thick-walled (wall up to $2 \mu \mathrm{m}$ thick), gradually thinning-out to the apex (thin-walled apical parts often collapsing), (54-) 56-123 (-132) × (3.2-) 3.7-7.3 ($8.3) \mu \mathrm{m}(n=87 / 8)$, solitary or in groups of $2-8$ (smooth parts) or up to 20 and more (in spines if present), easily breaking in microscopic slides; hymenial cystidia abundant in young basidiocarps, thin-walled, tubular-clavate to barrel- or bulletshaped, 18-32 × 4-8 $\mu \mathrm{m}$. Hyphidia present, associated with cystidia, simple or sparsely branched, often with thickened walls at the basal part, 2-2.5 $\mu \mathrm{m}$ in diam. at the apex, or distributed among basidia and basidioles, variably branched, mostly embedded, 1-2.5 $\mu \mathrm{m}$ in diam. at the apex. Crystals abundant in young basidiocarps, rare in older ones, acicular or in variably shaped agglomerations, up to $10 \mu \mathrm{m}$ in widest dimension. Basidia 2-4-celled, sphaeropedunculate, 7.5$11.5 \times 6-9 \mu \mathrm{m}$; stipe up to $9 \times 3.5 \mu \mathrm{m}$, sterigmata up to $12 \times 2-3 \mu \mathrm{m}$. Basidiospores broadly cylindrical to broadly ellipsoid, more rarely lacrymoid or pyriform, in exceptional cases subglobose, (4.1-) 4.2-9.3 (-9.8) × (3.5-) 3.8-5.8 (6.0) $\mu \mathrm{m}(n=380 / 13), \mathrm{L}=5.09-7.83, \mathrm{~W}=4.13-5.02$, $\mathrm{Q}^{\prime}=(1.1-)$ 1.2-2.2 (-2.6), Q = 1.24-1.74.

Distribution and ecology. Europe (Finland, France, Norway, Slovenia, Sweden), North America (Canada, British Columbia; USA, Washington; Mexico, Vera Cruz), Asia (Kyrgyzstan, Siberia, Russian Far East); on fallen logs and dead branches of conifers (Abies, Picea, Pinus, Thuja).

Remarks. The species was introduced as Heterochaetella brachyspora by Luck-Allen (1960) with the type specimen collected in France and labelled by Bourdot as Heterochaetella dubia var. mesochaeta f. brachyspora. However, Luck-Allen's idea about spore shape and size as the main diagnostic features of this species cannot be maintained. After re-studying the isotype of $H$. brachyspora, we concluded that it is identical with specimens collected from coniferous wood throughout the northern hemisphere. Those collections (of which six were sequenced) show the widest spore variation range within the genus. However, they can undoubtedly be addressed to this species due to other morphological features, i.e., clearly gelatinized and rather thick basidiocarps and apically very thin-walled and often collapsing, fragile tramal cystidia. Protomerulius brachysporus is the only conifer-dwelling species so far recognized in the genus. This host preference helps in identification of juvenile specimens possessing thinner basidiocarps and smaller basidiospores which otherwise can be mixed up with other effused non-poroid representatives of the genus.

Protomerulius commotus Spirin \& V. Malysheva, sp. nov.-Figs. $6 \mathrm{f}$ and 8.

MB 830955

Holotype. Norway. Vestfold: Larvik, Jordstøyp i Kvelde, Ulmus glabra, 15.IX.2016 Spirin 11097 (O).

Etymology. Commotus (Lat., adj.)—unsteady, dubious.

Basidiocarps effused, smooth, first reticulate, semitranslucent, greyish in fresh condition, then at least partly continuous, dirty-brownish when old or dry, gelatinized, up to $2 \mathrm{~cm}$ in widest dimension, $0.05-0.1 \mathrm{~mm}$ thick, margin concolorous with hymenium, gradually thinning-out. 


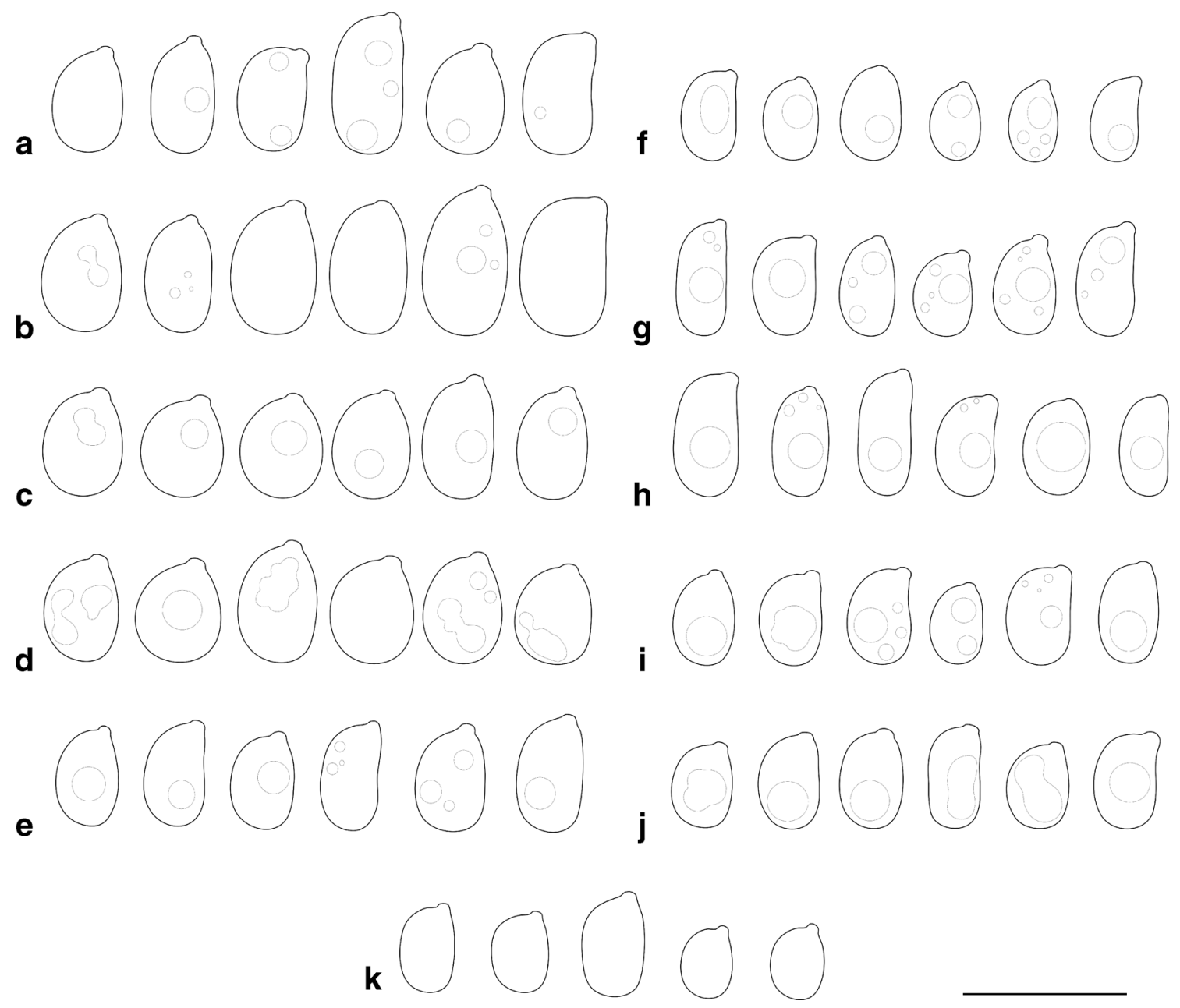

Fig. 6 Basidiospores of Protomerulius spp.: a Protomerulius dubius (lectotype); b $H$. dubia f. crassior (lectotype); c - P. brachysporus (isotype); d H. dubia f. sphaerospora (lectotype); e P. hebes (holotype);

f $P$. commotus (holotype); g P. madidus (holotype); h P. pertusus (holotype); i P. subreflexus (Miettinen 14402.1); j P. substuppeus (Vlasák 1407/38); k P. brasiliensis (lectotype). Scale bar $=10 \mu \mathrm{m}$

Hyphal structure monomitic; hyphae clamped, subicular hyphae with distinct walls, subparallel and densely packed,

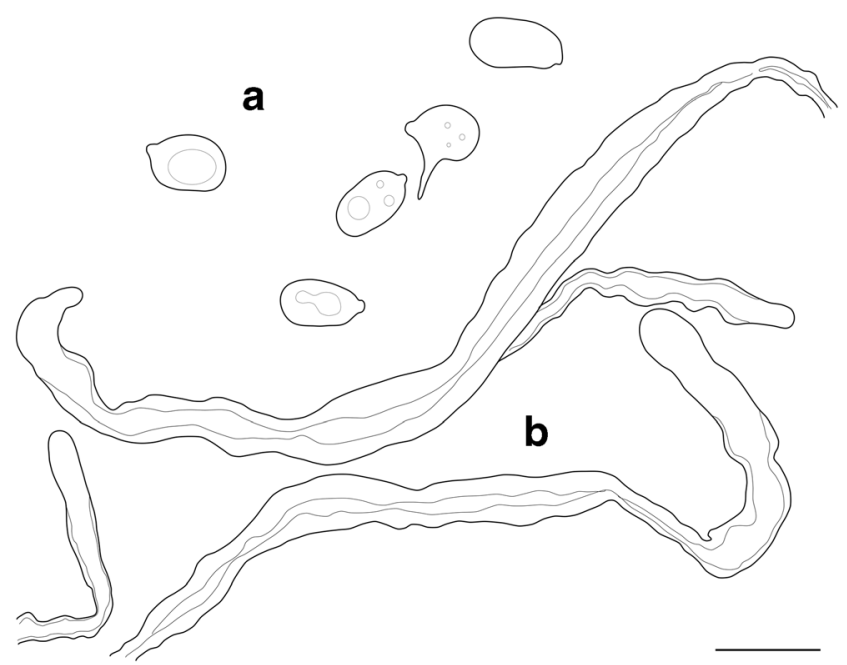

Fig. 7 Protomerulius brachysporus (Vehmaa 2600): a basidiospores; b cystidia. Scale bar $=10 \mu \mathrm{m}$
1-2 $\mu \mathrm{m}$ in diam., subhymenial hyphae thin-walled, 2-3 $\mu \mathrm{m}$ in diam., often short-celled, densely glued together. Tramal cystidia abundant, hyaline or very pale brownish, tubular-clavate, sturdy, with thickened (up to $2.5 \mu \mathrm{m}$ ) walls gradually thinning-out towards the apical part, longest cystidia slightly tapering to or widened at the apex (thin-walled apical parts often collapsing), (64.5-) 65-149 (-154) × (5.1-) 5.2-7.7 (7.8) $\mu \mathrm{m}(n=24 / 2)$, solitary or more often in groups of $2-8$, often biradicate; hymenial cystidia hyaline, broadly clavate, thin- or slightly thick-walled, $16.5-50 \times 4.2-8.2 \mu \mathrm{m}$, distributed mostly solitary or rarely associated with tramal cystidia. Hyphidia present, normally associated with cystidia, 1$1.5 \mu \mathrm{m}$ in diam. at the apex, thin-walled. Crystals occasionally present on hyphidia and cystidia, acicular or arranged in stellate agglomerations. Basidia 4-celled, sphaeropedunculate, 7 $9 \times 6-7.5 \mu \mathrm{m}$; stipe up to $6 \times 2.5 \mu \mathrm{m}$, sterigmata up to $8 \times 2-$ $2.5 \mu \mathrm{m}$. Basidiospores broadly cylindrical to broadly ellipsoid, more rarely lacrymoid, (4.3-) 4.4-6.2 (-6.3) $\times(3.0-)$ $3.2-4.1(-4.2) \mu \mathrm{m}(n=60 / 2), L=5.24-5.51, W=3.45-3.51$, $Q^{\prime}=(1.3-) 1.4-1.7(-1.9), Q=1.50-1.61$. 
Fig. 8 Protomerulius commotus (holotype): a hymenial cystidia; b tramal cystidia; $\mathbf{c}$ basidiospores.

Scale bar $=10 \mu \mathrm{m}$

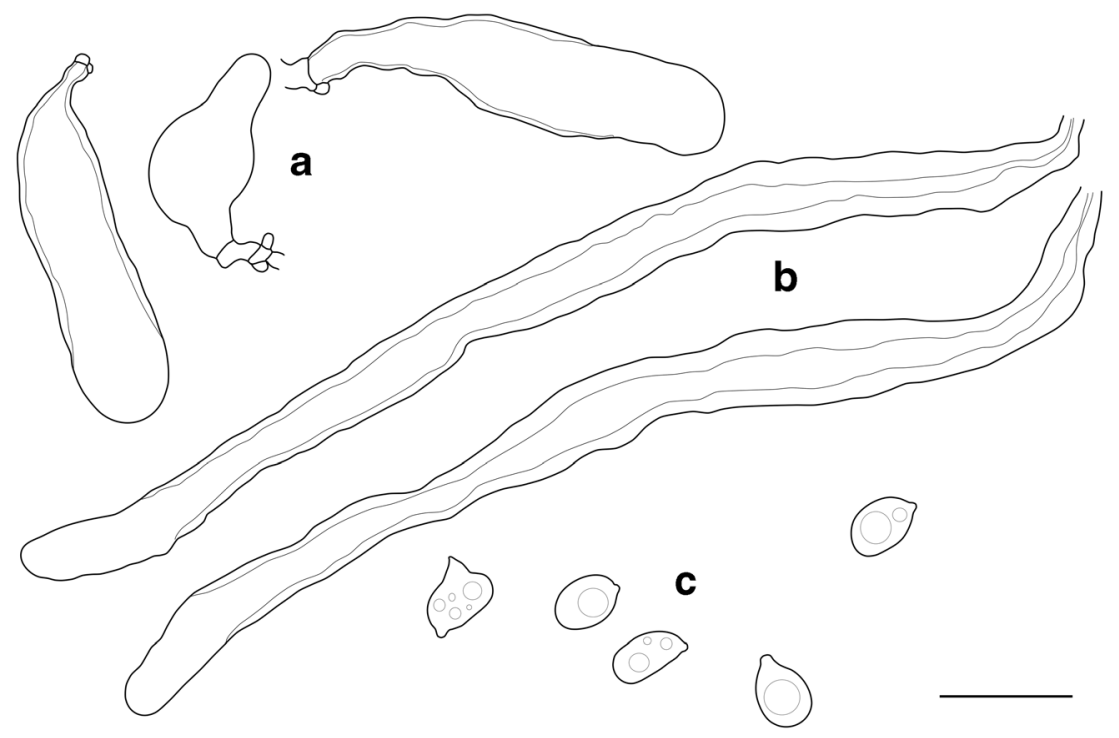

Distribution and ecology. Europe (Norway); on rotten wood of Ulmus glabra. So far known from the type locality only.

Remarks. Protomerulius commotus produces thin, smooth, gelatinized basidiocarps almost invisible in dry condition. Both morphologically and phylogenetically, it is close to P. madidus (introduced below). Basidiospores of $P$. commotus are smaller than in most collections of P. madidus studied by us albeit their variation ranges are overlapping. The best microscopic character for separating the two species is a presence of thin-walled, broadly clavate hymenial cystidia in P. commotus. In senecent hymenium, they often collapse and leave large empty cavities among hymenial cells; this feature has never been observed in P. madidus.

Protomerulius dubius (Bourdot \& Galzin) Spirin \& V. Malysheva, comb. nov.-Fig. 6a.

MB 830957.

$\equiv$ Heterochaete dubia Bourdot \& Galzin, Bull. Soc. Mycol. France 25: 30, 1909. Lectotype. France. Aveyron: Millau, Trou d'Enfer, Fraxinus excelsior, 18.IV.1907 Galzin 2022 (herb. Bourdot 4579) (PC, studied) (selected by Roberts 1998: 216).

Basidiocarps effused, smooth or covered by minute, irregularly arranged warts, first floccose, reticulate, white or cream-colored, then continuous, pale ochraceous to brownish, with darker gelatinized spots on hymenial surface, older basidiocarps gelatinized, waxy, dirty-brownish but exposing irregularly distributed whitish floccose patches, up to $3 \mathrm{~cm}$ in widest dimension, $0.05-0.1 \mathrm{~mm}$ thick, margin narrow, concolorous with or slightly paler than hymenial surface, pruinose.

Hyphal structure monomitic; hyphae clamped, subicular hyphae with distinct walls, $1-2 \mu \mathrm{m}$ in diam., subhymenial hyphae thin- or only slightly thick-walled, $2-3 \mu \mathrm{m}$ in diam. Tramal cystidia abundant, brownish, tubular-clavate, flexuous, easily breaking apart, with thickened (up to $1-2.5 \mu \mathrm{m}$ ) walls gradually thinning-out to the apex, (63-) 70-94 ($112) \times(3.8-) 4.1-8.7(-8.8) \mu \mathrm{m}(n=20 / 2)$, normally glued in fascicles of 2-8; hymenial cystidia absent. Hyphidia occasionally present, $1-2 \mu \mathrm{m}$ in diam. at the apex, thin-walled, simple or sparsely branched. Crystals abundant, encrusting hyphae and hyphidia, acicular or more often arranged in stellate agglomerations up to $12 \mu \mathrm{m}$ in diam. Basidia 4-celled, sphaeropedunculate, $8-9 \times 6-8 \mu \mathrm{m}$; stipe up to $6 \times 3 \mu \mathrm{m}$, sterigmata up to $7.5 \times 2-2.5 \mu \mathrm{m}$. Basidiospores broadly cylindrical to ellipsoid, more rarely lacrymoid, (5.1-) 5.2-8.0 ($8.2) \times(3.3-) 3.7-4.7(-4.8) \mu \mathrm{m}(n=150 / 5), L=5.85-6.37$, $W=3.98-4.20, Q^{\prime}=(1.1-) 1.2-2.0(-2.1), Q=1.46-1.55$.

Distribution and ecology. Europe (Estonia, Finland, France, Russia); on rotten wood of deciduous trees (Alnus, Fagus, Fraxinus, Populus).

Remarks. Bourdot \& Galzin (1909) described this species from the southern part of France and then introduced a number of varieties and forms (Bourdot \& Galzin 1928). Of them, only H. dubia var. dasychaeta represents $H$. dubia sensu orig. (Reid 1990), and it was typified by Roberts (1998). In turn, Heterochaetella dubia var. dasychaeta f. sphaerospora, as well as two forms of var. mesochaeta (f. brachyspora and $\mathrm{f}$. crassior) belong to Protomerulius brachysporus (see above) while var. psilochaeta is Mycostilla vermiformis (Berk. \& Broome) Spirin \& V. Malysheva (Spirin et al. 2019a).

Protomerulius dubius is most similar to P. pertusus, but it differs in having slightly wider basidiospores and clearly broader cystidia. Macroscopically, juvenile basidiocarps of these species are confusingly similar, being floccose and almost white. However, at maturity, they certainly look different when the hymenium of $P$. dubius obtains strongly gelatinized 
and darker colored areas while $P$. pertusus remains almost unchanged.

Protomerulius hebes Spirin \& Ryvarden, sp. nov.-Fig. $6 \mathrm{e}$.

\section{MB 830958}

Holotype. Ethiopia. Oromia: Arussi, Munessa Forest, hardwood, 15.VII.1990 Ryvarden 28406 (O F-903270, isotype H).

Etymology. Hebes (Lat., adj.) - faded.

Basidiocarps effused, smooth or covered by minute, irregularly arranged warts, floccose, reticulate, white to pale cream-colored or greyish, only partly slightly gelatinized, up to $2 \mathrm{~cm}$ in widest dimension, $0.05-0.1 \mathrm{~mm}$ thick, margin narrow, concolorous with hymenial surface, gradually thinning-out.

Hyphal structure monomitic; hyphae clamped, subicular hyphae thin- or slightly thick-walled, subparallel, $1.5-2 \mu \mathrm{m}$ in diam., subhymenial hyphae thin-walled, short-celled, 1.5$3 \mu \mathrm{m}$ in diam. Tramal cystidia abundant, hyaline to brownish, tubular-clavate, with thickened (up to $1 \mu \mathrm{m}$ ) walls gradually thinning-out to the apex, (58-) 69-90 (-111) × (3.2-) 3.3-4.3 $(-4.8) \mu \mathrm{m}(n=14 / 1)$, normally in fascicles of 3-15; hymenial cystidia thin-walled, tubular-clavate, somewhat tapering to the apex, some with refractive cyanophilous content (gloeocystidia), 20-36 × 4-7.5 $\mu \mathrm{m}$, distributed mostly solitary or rarely associated with tramal cystidia. Hyphidia occasionally present, $1-1.5 \mu \mathrm{m}$ in diam. at the apex, thin-walled, mostly associated with cystidia. Crystals abundant, encrusting hyphae and hyphidia, arranged in stellate agglomerations up to $20 \mu \mathrm{m}$ in diam. Basidia 4-celled, sphaeropedunculate, 9-10 × 7-8 $\mu \mathrm{m}$; stipe up to $6 \times 3 \mu \mathrm{m}$, sterigmata up to $7 \times 2.5-3 \mu \mathrm{m}$. Basidiospores broadly cylindrical to narrowly ellipsoid, more rarely lacrymoid, (5.5-) 5.6-7.0 (-7.1) × (3.1-) 3.2-4.1 (4.2) $\mu \mathrm{m}(n=30 / 1), L=6.21, W=3.68, Q^{\prime}=(1.5-) 1.6-1.9(-$ 2.2), $Q=1.69$.
Distribution and ecology. Africa (Ethiopia); on rotten wood of deciduous tree. So far known from the type locality only.

Remarks. Due to soft, floccose basidiocarps, Protomerulius hebes is reminiscent of P. pertusus. However, it produces abundant hymenial cystidia similar to those of $P$. commotus, and its tramal cystidia are shorter and somewhat narrower than in P. pertusus.

Protomerulius madidus Spirin \& K.H. Larss., sp. nov.Figs. $4 \mathrm{c}, \mathrm{d}, 6 \mathrm{~g}$, and 9.

MB 830959

Holotype. Norway. Buskerud: Lier, Stokkerinden, Ulmus glabra, 29.IX.2018 Spirin 12492 (O, isotypes-H, LE).

Etymology. Madidus (Lat., adj.)—humid.

Basidiocarps effused, smooth, first reticulate but quickly turning to continuous, semitranslucent, bluish-greyish in fresh condition, dirty-brownish when old or dry, with occasional craters, gelatinized, up to $5 \mathrm{~cm}$ in widest dimension, $0.07-$ $0.2 \mathrm{~mm}$ thick, margin concolorous with hymenium, gradually thinning-out; tiny white spots often present in mature basidiocarps, irregularly spread on hymenial surface.

Hyphal structure monomitic; hyphae clamped, thin-walled, $1.5-3 \mu \mathrm{m}$ in diam., in subhymenium often short-celled and densely glued together. Tramal cystidia abundant, hyaline or very pale brownish, tubular-clavate, sturdy, with thickened (up to $4 \mu \mathrm{m}$ ) walls gradually thinning-out towards the apical part, longest cystidia slightly tapering to the apex, (62-) 67$184(-208) \times(4.2-) 4.8-10.4(-12.0) \mu \mathrm{m}(n=168 / 15)$, solitary or in groups of $2-6$, occasionally bi- or multiradicate; hymenial cystidia absent. Hyphidia present, normally associated with cystidia, $1-2 \mu \mathrm{m}$ in diam. at the apex, thin-walled, occasionally producing hyphal pegs up to $70 \times 20 \mu \mathrm{m}$. Crystals present, encrusting basal hyphae but sometimes occurring on hyphidia and cystidia, acicular or arranged in stellate agglomerations, in some collections rare or evidently
Fig. 9 Protomerulius madidus (Larsson 17664): a basidiospores; b cystidia and crystals; $\mathbf{c}$ basidium. Scale bar $=10 \mu \mathrm{m}$

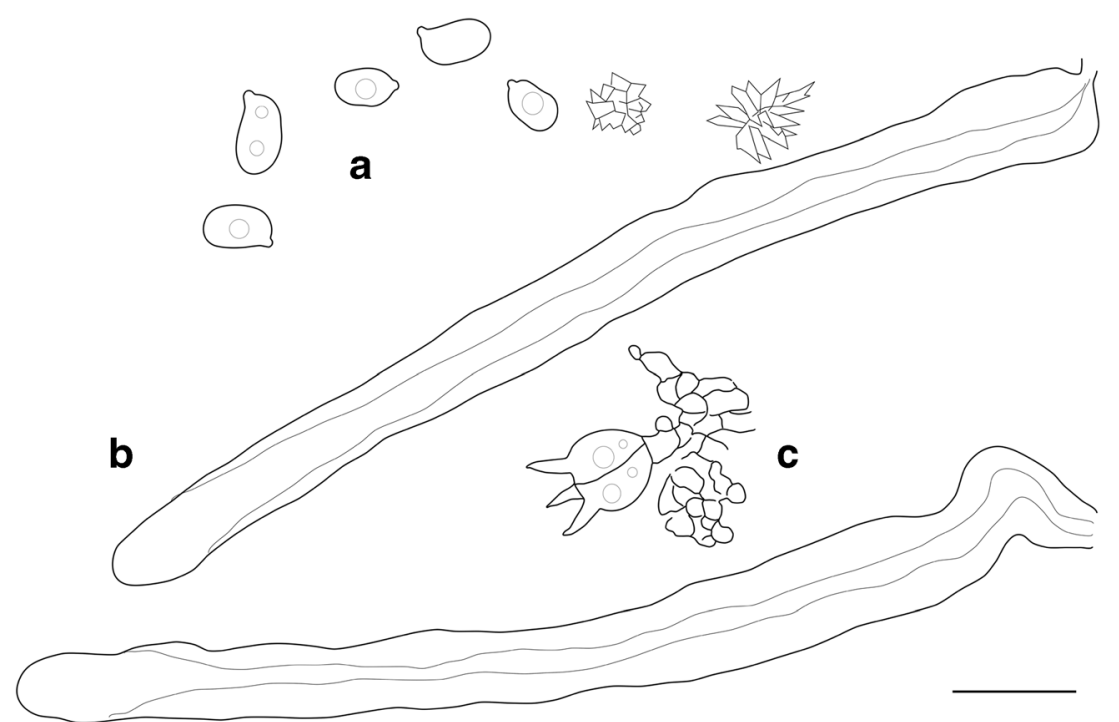


absent. Basidia 4-celled, sphaeropedunculate, 7.5-10 × 6.5$8 \mu \mathrm{m}$; stipe up to $6 \times 3.5 \mu \mathrm{m}$, sterigmata up to $7 \times 2-$ $2.5 \mu \mathrm{m}$. Basidiospores broadly cylindrical to ellipsoid, more rarely lacrymoid, (4.3-) 4.8-8.2 (-8.8) × (2.9-) 3.1-4.3 (4.6) $\mu \mathrm{m}(n=570 / 19), L=5.32-7.15, W=3.45-3.96$, $Q^{\prime}=(1.3-)$ 1.4-2.3 (-2.4), $Q=1.48-2.04$.

Distribution and ecology. Europe (Estonia, Norway, Ukraine); on rotten wood of deciduous trees (Alnus, Betula, Fraxinus, Ulmus).

Remarks. Protomerulius madidus is characterized by thin, hygroscopic basidiocarps becoming rather tough and almost invisible in dry condition. Macroscopically, it is indistinguishable from the closely related $P$. commotus; their microscopic differences are discussed under the latter species. Protomerulius brachysporus also possesses gelatinized basidiocarps but they are thicker and well-visible when dry. Additionally, P. brachysporus is restricted to coniferous hosts, and it has fragile, apically collapsing cystidia, as well as wider basidiospores. Senescent basidiocarps of $P$. dubius are often partly gelatinized and thus can be mixed up with $P$. madidus but they are essentially softer, waxy. Moreover, cystidia of $P$. dubius easily break in microscopic slides and its basidiospores are on average slightly wider than in P. madidus.

Protomerulius microsporus (Burt) Spirin \& V. Malysheva, comb. nov.-Fig. 10.

MB 830960

$\equiv$ Heterochaete microspora Burt, Ann. Missouri Bot. Gdn 8: 376, 1921. Holotype. Mexico. Vera Cruz: Córdoba, Motzorongo, 15.I.1910 Murrill 990 (NY 00738344, studied).

Basidiocarps effused, first warted, floccose, pale creamcolored, then continuous, distinctly hydnoid, covered by spine-like projections up to $400 \mu \mathrm{m}$ long, 3-5 per mm, ceraceous, pale ochraceous to greyish, slightly gelatinized, up to $4 \mathrm{~cm}$ in widest dimension, $0.1-0.3 \mathrm{~mm}$ thick, margin narrow, concolorous with hymenial surface, floccose or compact, partly detaching.
Hyphal structure dimitic; hyphae clamped. Skeletal hyphae hyaline to brownish, slightly to distinctly thick-walled (wall up to $2 \mu \mathrm{m}$ thick), flexuous, (1.8-) 1.9-3.8 (-3.9) $\mu \mathrm{m}$ in diam. $(n=20 / 1)$; generative hyphae dominating, thin- or only slightly thick-walled, $1.5-3 \mu \mathrm{m}$ in diam., subparallel in subiculum, ascending in subhymenium. Tramal cystidia present as endings of skeletal hyphae at the apices of spines, with thickened, gradually thinning-out walls, 4-7 $\mu \mathrm{m}$ in diam., accidentally branched at the top, intermixed with generative hyphae in large fascicles; gloeocystidia abundant in senescent hymenium, clavate to somewhat moniliform, yellowish, 12-23 $\times 3-$ $6.5 \mu \mathrm{m}$. Hyphidia occasionally present, $1.5-2.5 \mu \mathrm{m}$ in diam. at the apex, thin-walled, embedded or slightly projecting. Crystals abundant, encrusting hyphae and hyphidia, acicular or arranged in stellate agglomerations. Basidia 4-celled, sphaeropedunculate, $8.5-10 \times 7-9 \mu \mathrm{m}$; stipe up to $9 \times 3 \mu \mathrm{m}$, sterigmata up to $8.5 \times 1.5-3 \mu \mathrm{m}$. Basidiospores narrowly to broadly ellipsoid, rarely subglobose, (4.4-) 4.7-6.7 ($6.8) \times(3.7-) 3.8-5.0(-5.1) \mu \mathrm{m}(n=60 / 2), L=5.41-6.10$, $W=4.14-4.39, Q^{\prime}=(1.1-) 1.2-1.6(-1.7), Q=1.24-1.48$.

Distribution and ecology. North America (Mexico-Vera Cruz); on rotten wood.

Remarks. Distinctly dimitic basidiocarps with pronounced spines differentiate P. microsporus from other effused members of the genus. The species is so far known from the central part of Mexico, but its actual distribution area may be much larger.

Protomerulius minor (Möller) Spirin \& Miettinen, comb. nov.-Figs. $4 \mathrm{~b}$ and 11.

MB 830961

三Stypella minor Möller, Bot. Mitth. Tropen 8: 77, 1895. Lectotype. Table 4, Fig. 7 in A. Möller, Bot. Mitth. Tropen 8, 1895 (selected here, MBT 387042). Epitype. Brazil. Pernambuco: Jaqueira, RPPN Frei Caneca, hardwood, 19.IV.2013 Larsson 15937 (O) (selected here, MBT 387043).
Fig. 10 Protomerulius microsporus (Ryvarden 23440): a gloeocystidia; b basidia; $\mathbf{c}$ tramal cystidia and crystals; $\mathbf{d}$ basidiospores. Scale bar $=10 \mu \mathrm{m}$

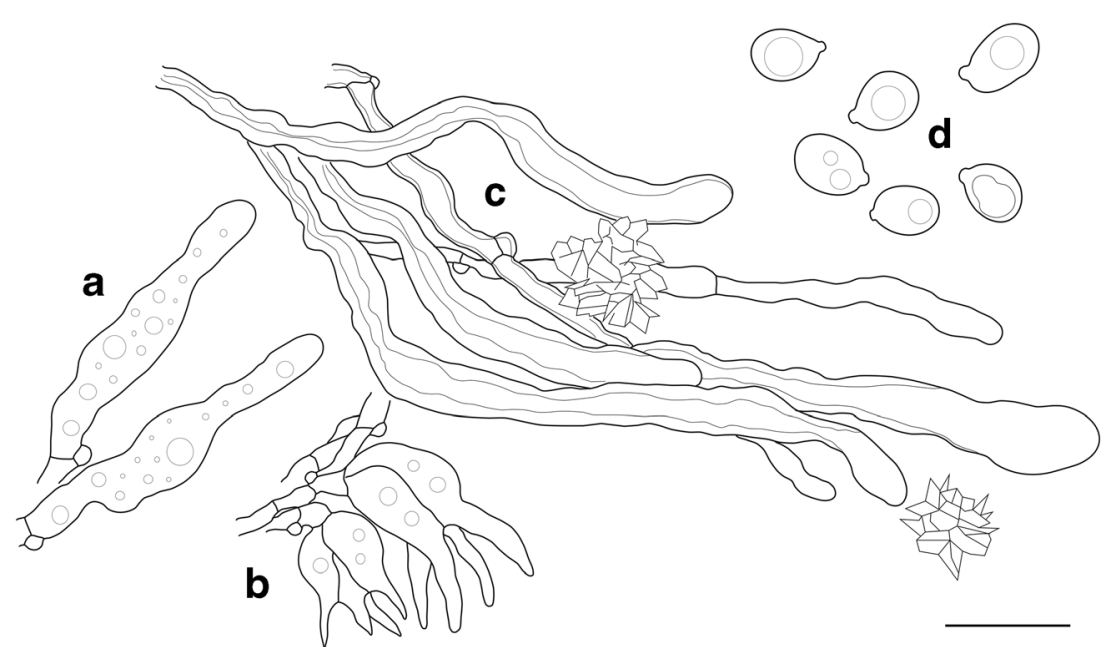


Fig. 11 Protomerulius minor (Miettinen 19586): a basidium; b cystidia; $\mathbf{c}$ basidiospores. Scale bar $=10 \mu \mathrm{m}$

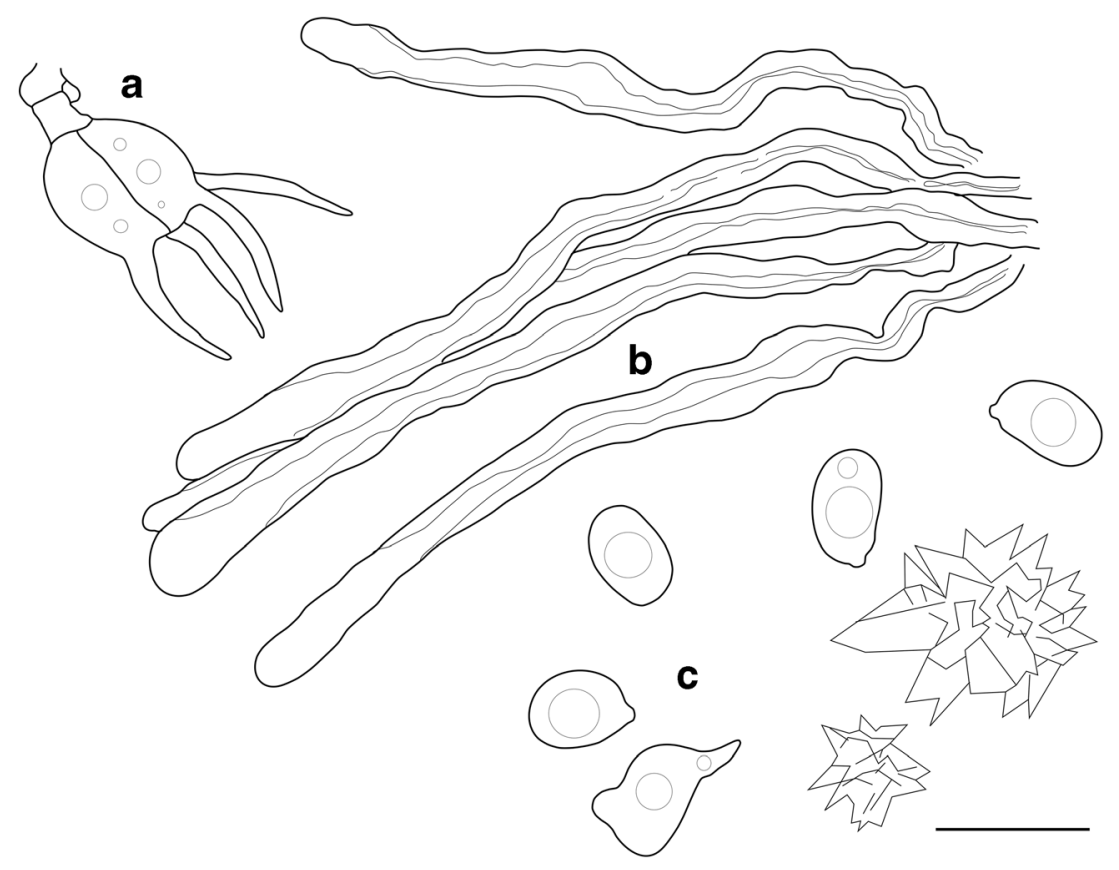

Basidiocarps effused, more or less regularly hydnoid, covered by spine-like projections up to $150 \mu \mathrm{m}$ long, $3-5$ per mm, first floccose, reticulate, pale cream-colored, then more compact but with craters or holes, pale ochraceous to greyish, partly gelatinized, up to $7 \mathrm{~cm}$ in widest dimension, 0.05 $0.15 \mathrm{~mm}$ thick, margin narrow, concolorous with or slightly paler than hymenial surface, gradually thinning-out.

Hyphal structure dimitic; hyphae clamped. Skeletal hyphae hyaline to brownish, slightly to distinctly thick-walled (wall up to $2 \mu \mathrm{m}$ thick), flexuous, (2.2-) 2.3-3.8 (-3.9) $\mu \mathrm{m}$ in diam. $(n=20 / 2)$; generative hyphae dominating, thin- or only slightly thick-walled, $1.5-2 \mu \mathrm{m}$ in diam., more or less subparallel in subiculum, interwoven in subhymenium. Tramal cystidia present as endings of skeletal hyphae at the apices of spines, with thickened, gradually thinning-out walls, projecting up to $50 \mu \mathrm{m}, 4-6 \mu \mathrm{m}$ in diam., in groups of 5-25; hymenial cystidia absent. Hyphidia occasionally present, $1-1.5 \mu \mathrm{m}$ in diam. at the apex, thin-walled, scattered among basidia. Crystals abundant, encrusting hyphae and hyphidia, acicular or arranged in large stellate agglomerations up to $15 \mu \mathrm{m}$ in diam. Basidia 4celled, sphaeropedunculate, $8-11 \times 7-9 \mu \mathrm{m}$; stipe up to $5 \times$ $3 \mu \mathrm{m}$, sterigmata up to $10 \times 2.5-3 \mu \mathrm{m}$. Basidiospores broadly cylindrical to broadly ellipsoid, more rarely lacrymoid, (4.9-) 5.0-8.0 (-8.2) × (3.0-) 3.2-5.0 (-5.2) $\mu \mathrm{m}(n=170 / 6), L=$ 5.87-7.06, $W=3.88-4.30, Q^{\prime}=(1.2-) 1.3-2.2(-2.3), Q=$ $1.49-1.83$.

Distribution and ecology. North America (USAArkansas, New York, North Carolina, Massachusetts, Tennessee, Virginia), South America (Brazil-Pernambuco, Santa Catarina); on dead wood of deciduous trees at various decomposition stages.
Remarks. Möller (1895) described Stypella minor from Brazil but the authentic material did not survive in Hamburg where some of his types were preserved (Friedrichsen 1977). His description refers to a resupinate fungus with papillose (under lens) hymenial surface and dimitic hyphal system ("aus sehr feinen, locker verwirrten Fäden gebildet, zwishen denen bündelartig angeordnet ... starke Fäden verlaufen"); the hymenophoral projections consist of cystidia-like endings of skeletal hyphae (Möller 1895: 77, Table 4, Fig. 7). These features, as well as basidia and basidiospores of $S$. minor as described in the protologue, well correspond to the hydnoid Protomerulius species widely distributed in North America and occurring also in Brazil. Therefore, we decided to use Möller's binomial for naming it. Here we combine S. minor in Protomerulius, designate the original illustration as a lectotype of this species and provide it with an epitype.

Protomerulius pertusus V. Malysheva \& Spirin, sp. nov.Figs. $6 \mathrm{~h}$ and 12.

MB 830962

Holotype. Norway. Møre og Romsdal: Nesset, Eikesdalen, Ulmus glabra, 16.IX.2014 Svantesson (O F75913).

Etymology. Pertusus (Lat., adj.) - pertusate.

Basidiocarps effused, smooth or covered by minute, irregularly arranged warts, first floccose, reticulate, white or pale cream-colored, then more compact but with craters or holes, pale ochraceous to greyish, in some parts only slightly gelatinized, up to $7 \mathrm{~cm}$ in widest dimension, $0.07-0.15 \mathrm{~mm}$ thick, margin narrow, concolorous with hymenial surface, gradually thinning-out. 
Fig. 12 Protomerulius pertusus (holotype): a basidia; $\mathbf{b}$ cystidia; $\mathbf{c}$ basidiospores. Scale bar $=10 \mu \mathrm{m}$
Hyphal structure monomitic; hyphae clamped, thin- or only slightly thick-walled, 1.5-2.5 (-3) $\mu \mathrm{m}$ in diam., subparallel in subiculum, ascending in subhymenium. Tramal cystidia abundant, hyaline to brownish, tubular-clavate, flexuous, with thickened (up to $1-1.5 \mu \mathrm{m}$ ) walls gradually thinning-out to the apex, (59-) 60-113 (-140) × (3.7-) 3.8-5.2 (-5.3) $\mu \mathrm{m}$ $(n=20 / 2)$, normally in groups of $3-10$; hymenial cystidia absent. Hyphidia occasionally present, $1.5-2 \mu \mathrm{m}$ in diam. at the apex, thin-walled, simple or sparsely branched. Crystals abundant, encrusting hyphae and hyphidia, acicular or arranged in stellate agglomerations up to $15 \mu \mathrm{m}$ in diam. Basidia 4-celled, sphaeropedunculate, $8-10 \times 7-9 \mu \mathrm{m}$; stipe up to $6 \times 3 \mu \mathrm{m}$, sterigmata up to $8.5 \times 2-2.5 \mu \mathrm{m}$. Basidiospores broadly cylindrical to narrowly ellipsoid, more rarely lacrymoid, (5.0-) $5.1-8.1(-8.2) \times(3.1-) 3.2-4.5(-4.6) \mu \mathrm{m}(n=150 / 5), L=$ $5.95-6.96, W=3.49-3.89, Q^{\prime}=(1.2-) 1.3-2.2(-2.5), Q=$ $1.56-1.94$.

Distribution and ecology. Europe (Norway, Russia); on rotten wood of deciduous trees (Corylus, Quercus, Ulmus).

Remarks. The soft, pale, arid basidiocarps of P. pertusus make it different from other species occurring in Europe. Microscopically, it is most similar to P. dubius; their differences have been discussed under the latter species. So far, $P$. pertusus has been detected in two localities - both are rich forests dominated by broad-leaved trees and famous for a high diversity of wood-inhabiting basidiomycetes.

Protomerulius subreflexus (Lloyd) Miettinen \& Ryvarden, comb. nov.-Figs. $4 \mathrm{e}$ and $6 \mathrm{i}$.

MB 830963

三Polystictus subreflexus Lloyd, Mycol. Writings 6: 884, 1919. Lectotype. Philippines. Luzon: Mt. Maquiling, dead wood, 23.IX.1917 Marquez \& Reinking (BPI 306707, studied) (selected by Stevenson \& Cash 1936: 139).
Basidiocarps sessile-pileate to effused-reflexed (projecting part $0.3-1 \mathrm{~cm}$ ) or totally resupinate, often partly fusing together. Pileal surface floccose, pale cream-colored to pale ochraceous, rarely indistinctly zonate. Pileal margin sharp to rather blunt, even, concolorous with pileal surface; margin of resupinate part pellicular-floccose, first almost white, then pale cream-colored to pale ochraceous, up to $1 \mathrm{~mm}$ wide. Pore surface even, pale cream-colored or yellowish to pale ochraceous, in older basidiocarps with scattered brownish spots; pores angular to lacerate, 2-4 per $\mathrm{mm}$, dissepiments even to somewhat serrate. Section: context $0.5-1 \mathrm{~mm}$ thick, homogeneous, pale cream-colored to pale ochraceous, cottony; tubes soft, 1-3 mm thick, concolorous with pore surface.

Hyphal structure dimitic; hyphae clamped. Skeletal hyphae hyaline to yellowish, dominating, flexuous, interwoven throughout, in context sometimes arranged in subparallel bundles, with distinctly thickened (up to $1-1.5 \mu \mathrm{m}$ ) walls, as a rule not encrusted, (2.7-) 2.8-4.2 (-4.3) $\mu \mathrm{m}$ in diam. in context $(n=20 / 2),(2.0-) 2.2-3.7(-3.8) \mu \mathrm{m}$ in diam. in tube trama $(n=120 / 4)$; apices of skeletals at dissepiment edges thin-walled, 5-5.5 $\mu \mathrm{m}$ in diam. Generative hyphae hyaline, thin- or slightly thick-walled, short-celled in subhymenium, $1.5-3.5 \mu \mathrm{m}$ in diam., in context accidentally inflated up to $6 \mu \mathrm{m}$ in diam. Gloecystidia present, thin-walled, tapering, 20-26 × 3.5-5.5 $\mu \mathrm{m}$. Crystals abundant, encrusting hyphae and hymenial cells, acicular or arranged in stellate agglomerations, up to $20 \mu \mathrm{m}$ in widest dimension. Basidia 4-celled, sphaeropedunculate, $6.5-8.5 \times 5-7.5 \mu \mathrm{m}$; stipe up to $7 \times$ $2.5 \mu \mathrm{m}$, sterigmata up to $4 \times 1.5-2 \mu \mathrm{m}$. Basidiospores ellipsoid to cylindrical, more rarely lacrymoid or almost subglobose, (4.7-) 4.8-7.1 (-7.2) × (3.2-) 3.5-4.9 (-5.0) $\mu \mathrm{m}$ $(n=120 / 4), L=5.62-6.29, W=3.96-4.20, Q^{\prime}=(1.1-) 1.2-$ $1.8(-1.9), Q=1.40-1.51$. 
Fig. 13 Protomerulius brasiliensis (syntype): a generative hyphae; $\mathbf{b}$ basidia; $\mathbf{c}$ tramal skeletal hyphae; $\mathbf{d}$ gloeocystidia. Scale bar $=10 \mu \mathrm{m}$

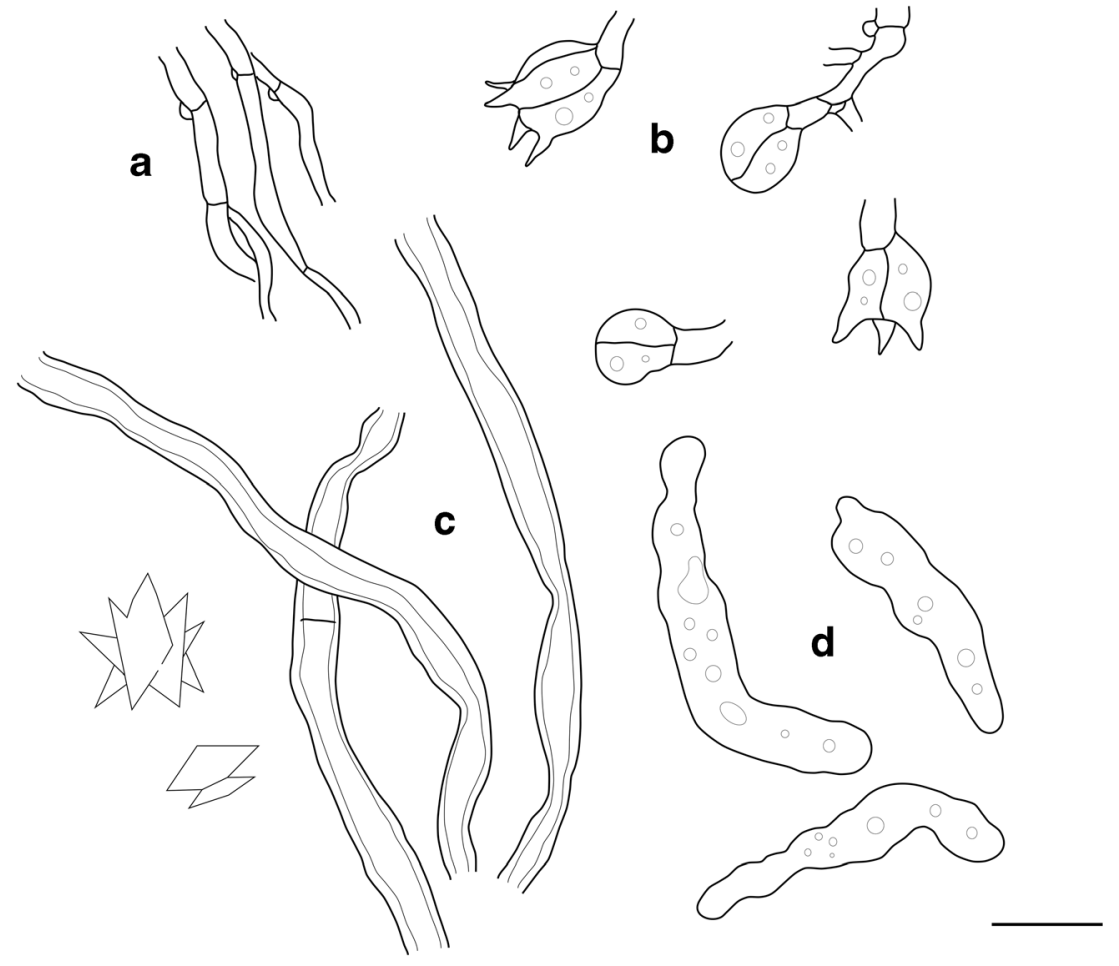

Distribution and ecology. Southeast Asia (China, Philippines, Indonesia); on fallen branches and logs of deciduous trees.

Remarks. Protomerulius subreflexus is the Asian sibling of P. substuppeus reintroduced here based on the type material and several recent collections used for DNA study. These species are morphologically almost indistinguishable, except that contextual and tramal hyphae of $P$. subreflexus are narrower than in P. substuppeus.

Protomerulius substuppeus (Berk. \& Cooke) Ryvarden, Syn. Fung. 5: 212, 1991.-Figs. 4f, 6j, k, and 13.

$\equiv$ Polyporus substuppeus Berk. \& Cooke, Bot. J. Linnean Soc. 15: 380, 1876. Lectotype. Brazil, (no exact locality indicated), dead wood, 1874, Trail 123 (K(M) 35121, studied) (selected by Ryvarden 1984: 358).

= Protomerulius brasiliensis Möller, Bot. Mitth. Tropen 8: 129, 1895. Lectotype. Brazil. Santa Catarina: Blumenau, Jacaratia dodecaphylla (recently fallen branches), 18911893 Möller 23 (HBG, studied) (selected by Bandoni et al. 1982: 1003).

Basidiocarps sessile-pileate to effused-reflexed (projecting part $0.5-3 \mathrm{~cm}$ ) or totally resupinate, often in gregarious groups and partly fusing together. Pileal surface indistinctly striate or radially fibrillose, first pale cream-colored to pale ochraceous, later darkening to brownish. Pileal margin sharp to rather blunt, even or slightly undulating, concolorous with pileal surface; margin of resupinate part pellicular-floccose, first almost white, then pale cream-colored to ochraceous or brownish, up to $2 \mathrm{~mm}$ wide. Pore surface even, pale creamcolored to ochraceous, in older or bruised basidiocarps with reddish-brown tints, in older basidiocarps uniformly brownish; pores angular to lacerate, first 3-5 per mm, then fusing together and reaching 1-3 per mm, dissepiments uneven to serrate. Section: context $1-5 \mathrm{~mm}$ thick, duplex, pale cream-colored to brownish, upper layer rather loose and more intensively colored than firmer lower layer, resinous zone occasionally present close to the tube layer; tubes soft, slightly agglutinated, 1-5 mm thick, concolorous with pore surface.

Hyphal structure dimitic; hyphae clamped. Skeletal hyphae hyaline to brownish, dominating, flexuous, interwoven or arranged in subparallel bundles in context, more or less strictly subparallel in tubes, with distinctly thickened (up to 1$1.5 \mu \mathrm{m}$ ) walls, sometimes covered by amorphous grainy matter, (3.8-) 3.9-5.8 $(-6.8) \mu \mathrm{m}$ in diam. in context $(n=20 / 1)$, (2.2-) 2.4-5.6 (-5.8) $\mu \mathrm{m}$ in diam. in tube trama $(n=80 / 4)$; apices of skeletals at dissepiment edges thin-walled, 5-6.5 $\mu \mathrm{m}$ in diam., sometimes with refractive contents. Generative hyphae hyaline, thin- or slightly thick-walled, short-celled in subhymenium, $1.5-3 \mu \mathrm{m}$ in diam. Gloeocystidia present, thin-walled, tapering or somewhat moniliform, 20-46 $\times 4$ $7 \mu \mathrm{m}$. Crystals abundant, encrusting hyphae and hymenial cells, acicular or arranged in stellate agglomerations, up to $10 \mu \mathrm{m}$ in widest dimension. Basidia 4-celled, sphaeropedunculate, $7-9 \times 6-7.5 \mu \mathrm{m}$; stipe up to $7 \times$ $3.5 \mu \mathrm{m}$, sterigmata up to $7 \times 2.5-3 \mu \mathrm{m}$. Basidiospores narrowly ellipsoid to cylindrical, more rarely lacrymoid or ovoid, 
(4.1-) 4.2-8.2 (-8.9) × (3.0-) 3.2-4.9 (-5.0) $\mu \mathrm{m}(n=210 / 7)$, $L=5.05-7.15, W=3.62-4.42, Q^{\prime}=(1.2-) 1.3-2.1 \quad(-2.2)$, $Q=1.34-1.76$.

Distribution and ecology. Africa (Uganda), North America (Costa Rica, Jamaica, Puerto Rico, US Virgin Islands), South America (Argentina, Missiones; Brazil, Paraná, Santa Catarina); on fallen branches and logs of deciduous trees.

Remarks. Bandoni et al. (1982) re-established $P$. brasiliensis as a resupinate fungus. Their opinion evidently originated from the photographs published by Möller (1895). An absence of caps is the only difference between $P$. brasiliensis and $P$. substuppeus treated in the current literature (cf. Ryvarden 2016). However, Möller himself described $P$. brasiliensis as producing caps ("consolenförmig abstehende"; Möller 1895: 131), and his two authentic collections in HBG contain several well-developed effused-reflexed or even sessile basidiocarps. Since we found no morphological characters to separate $P$. brasiliensis and $P$. substuppeus, we consider them as taxonomic synonyms. Protomerulius substuppeus was also described from Brazil, and it has priority over $P$. brasiliensis. Identity of $P$. substuppeus versus $P$. africanus (described from Kenya) deserves further study. The only African collection used in the present study came from Uganda. It is morphologically identical to other specimens of $P$. substuppeus studied by us and shows only small differences in ITS sequence. However, more material and tefl sequences of $P$. africanus are required to conclude if it represents a separate species.

Key to non-poroid Protomerulius species in temperate Northern Hemisphere

1. On deciduous trees. Basidiocarps floccose or waxy ... 2

(1). On conifers. Basidiocarps waxy or gelatinized, greyish to ochraceous-brown P. brachysporus

2. Basidiocarps semitranslucent when fresh, hardly visible when dry ..................................... 3

(2). Basidiocarps floccose or waxy, remaining visible in dry condition ..................................... 4

3. Hymenial cystidia present, broadly clavate. $L=5.24$

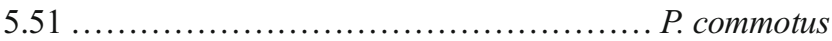

(3). Hymenial cystidia absent. $L=5.32-7.15$ P. madidus

4. Hymenophore smooth or indistinctly warted. European

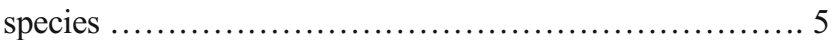

(4). Hymenophore hydnoid. North American species P. minor

5. Basidiocarps remaining pale-colored and floccose. $W=$ 3.49-3.89 .............................. Pertusus

(5). Basidiocarps first pale-colored, floccose, then darker and partly gelatinized. $W=3.98-4.20$
Psilochaete Spirin \& V. Malysheva, gen. nov. MB 830964

Etymology. From Psilos (Greek, adj.) —eminent, and "chaete."

Basidiocarps effused, smooth, reticulate, semitranslucent, thin. Hyphal structure monomitic; hyphae clamped, thinwalled. Cystidia abundant, clavate to skittle-like, thin-walled. Hyphidia present, crystal aggregations absent. Basidia 4celled, globose, sessile or with a strongly reduced stipe. Basidiospores broadly cylindrical to narrowly ellipsoid. On rotten wood.

Type species. Psilochaete multifora.

Psilochaete multifora Spirin \& V. Malysheva, sp. nov.Fig. 14.

MB 830965.

Holotype. Norway. Møre og Romsdal: Nesset, Eikesdalen, Ulmus glabra, 27.IX.2017 Spirin 11596 (O, isotypes H and LE).

Etymology. Multiforus (Lat., adj.)—perforated.

Basidiocarps effused, smooth, reticulate, semitranslucent, bluish-greyish in fresh condition, greyish-brownish when old or dry, gelatinized, up to $1 \mathrm{~cm}$ in widest dimension, $0.03-$ $0.05 \mathrm{~mm}$ thick, margin concolorous with hymenium, gradually thinning-out.

Hyphal structure monomitic; hyphae clamped, thin-walled, 1-1.5 $\mu \mathrm{m}$ in diam., densely arranged. Cystidia abundant, clavate to skittle-like, thin-walled, 32-48 × 4.5-7.5 $\mu \mathrm{m}$, solitary or in groups of 2-5. Hyphidia present, normally associated with cystidia, $0.5-0.8 \mu \mathrm{m}$ in diam. at the apex, thin-walled. Crystals absent. Basidia 4-celled, globose, 7-8 $\mu \mathrm{m}$ in diam., sessile or with a strongly reduced stipe up to $1 \times 1 \mu \mathrm{m}$, sterigmata up to $3.5 \times 1.5 \mu \mathrm{m}$. Basidiospores broadly cylindrical to narrowly ellipsoid, (4.8-) 5.1-6.2 × (2.9-) 3.0-3.8 (-3.9) $\mu \mathrm{m}$ $(n=30 / 1), L=5.62, W=3.36, Q^{\prime}=(1.4-) 1.5-1.9(-2.0), Q=$ 1.68 .

Distribution and ecology. Europe (Norway); on rotten wood of Ulmus glabra. So far known from the type locality only.

Remarks. From similar-looking effused Protomerulius spp., P. multifora differs by considerably shorter, thin-walled cystidia and predominantly sessile basidia.

\section{Excluded taxa}

Heterochaetella alba Rick, Iheringia Botanica 2: 42, 1958. Invalidly published species, no type indicated.

Heterochaetella bispora Luck-Allen, Canadian J. Bot. 38: 563, 1960.

The type specimen of $H$. bispora represents a juvenile individual of Myxarium crozalcii (Bourdot \& Galzin) Spirin \& V. Malysheva infected by an anamorphic fungus (Spirin et al. 2019b). 
Fig. 14 Psilochaete multifora (holotype): a basidia; b basidiospores; $\mathbf{c}$ cystidia and hyphidia. Scale bar $=10 \mu \mathrm{m}$
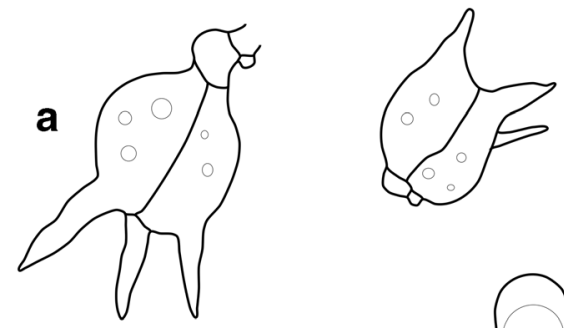

b
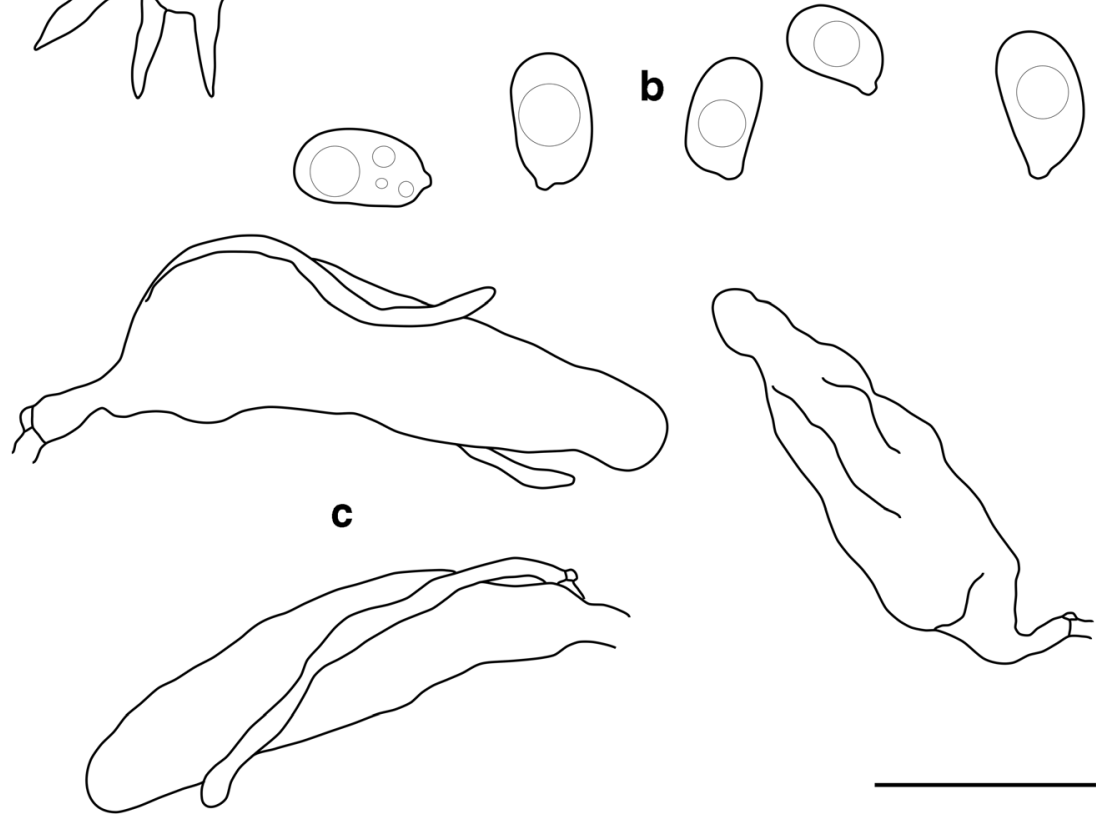

Heterochaetella crystallina Bourdot, Trans. British Mycol. Soc. 7: 53, 1921.

A synonym of Mycostilla vermiformis (Berk. \& Broome) Spirin \& V. Malysheva (Spirin et al. 2019a).

Heterochaetella ochracea Viégas, Bragantia 5: 241, 1945. Accepted as a member of Eichleriella (Alvarenga et al. 2019).

Protohydnum piceicola Kühner ex Bourdot, Bull. Soc. Mycol. France 48: 205, 1932.

The type species of Hyalodon (Malysheva et al. 2018). The single collection located in Bourdot's herbarium and labelled by him as P. piceicola is selected here as a lectotype: Sweden. Uppland: Uppsala, Storvreta, Picea abies, 4.X.1927 Lundell 13 (herb. Bourdot 41808) (PC) (MBT 387044).

Protomerulius farlowii Burt, Annals Missouri Bot. Gdn. 6: 176, 1919.

Accepted as a member of Stypellopsis (Spirin et al. 2019a).

Protomerulius javensis Burt, Annals Missouri Bot. Gdn. 11: 41, 1924.

Coriaceous, dark-colored, semiporoid basidiocarps, large basidia and long cylindrical basidiospores described in the protologue (Burt 1924) preclude affinities of P. javensis with taxa included in the present study.

Sebacina pruinosa McNabb, New Zealand J. Bot. 7: 243, 1969.
According to the protologue (McNabb 1969), S. pruinosa may be related to P. commotus and P. madidus. Newly collected and sequenced specimens from New Zealand are needed to re-establish this species.

Specimens examined (sequenced collections are marked by asterisk).

Heterochaetella bispora. Canada. Ontario: Brant Co., New Durham, Ulmus sp., 30.VIII.1937 Cain (TRTC 17594).

Metulochaete sanctae-catharinae. Brazil. Acre: CazumbáIracema Resex, hardwood, 30.I.2016 Meiras-Ottoni AM 0678* (URM 93055, O, H); Floresta Nacional Macauã, Amazon Forest, dead wood, I.2016 Meiras-Ottoni AR22 (URM 93056, O, H).

Protomerulius brachysporus. Finland. Varsinaissuomi: Lohja, Osuniemi, Picea abies, 1.X.1937 Laurila (H ex HPP 1974). Uusimaa: Espoo, Glimsån, P. abies, 21.IX.1999 Vehmaa 2600* (H). France. Aveyron: Causse Noir, Juniperus sp., 30.XI.1913 Galzin 14648 (herb. Bourdot 13712) (PC), Pinus sp. (lectotypes of Heterochaetella dubia f. crassior and f. sphaerospora, see above). Var: Toulon (holotype, see below). Kyrgyzstan. Naryn: Moldo Too, Picea schrenkiana, 31.VII.1967 Raitviir (TAAM 044584). Mexico. Tlaxcala: Parada don Conejo, coniferous wood, 21.IX.1985 Ryvarden 23195* (O). Norway. Oslo: Bygdøy, Holsts veg, 19.XI.1972 Høiland (O F165304). Buskerud: Modum, Askerrudbekken, P. abies, 13.X.2008 Hofton 08896* (O 
F293193). Hedmark: Ringsaker, Helgøya, softwood, 17.X.1981 Høgholen 409/81 (O F102104). Russia. Krasnoyarsk Reg.: Yermakovsky Dist., Lobanova, Abies sibirica, 26.VIII.1958 Parmasto (TAAM 009126). Primorie: Terney Dist., Sikhote-Alin Nat. Res., Abies nephrolepis, 30.IX.1979 Parmasto (TAAM 102746*). Slovenia: Prekmurje, Boreča, Pinus nigra, 23.III.1939 Lindtner 4861 (H ex O). Sweden. Norrbotten: Boden, Blåkölen, P. abies, 18.IX.2010 J. Nordén 6743* (O). USA. Washington: Pierce Co., Pack Forest, Thuja plicata (bark of living branch), 10.X.2014 Spirin 8351c* $(\mathrm{H})$.

Protomerulius commotus. Norway. Vestfold: Larvik, Jordstøyp i Kvelde, Ulmus glabra, 15.IX.2016 Spirin 11097* (O, holotype), Spirin 11110*(O).

Protomerulius dubius. Estonia. Pärnumaa: Lääneranna, Hanila, very rotten log, 28.VI.1963 Parmasto (TAAM 016488). Finland. Sipoo: Östersundom, Alnus glutinosa, 2.VIII.1996 Saarenoksa 14396* (H). France. Aveyron (lectotype, see below). Russia. Adygea: Maykop Dist., Guzeripl, Fagus sylvatica, 17.IX.2003 Kotiranta 22589 (H). Nizhny Novgorod Reg.: Lukoyanov Dist., Razino, Populus tremula, 18.VIII.2009 Spirin 3019* (H).

Protomerulius hebes. Ethiopia. Oromia: Arssi, Munessa Forest, hardwood, 15.VII.1990 Ryvarden 28406* (O, holotype).

Protomerulius madidus. Estonia. Valgamaa: Urgemägi, Fraxinus excelsior, 14.IX.2015 Spirin 9845*(H). Norway. Vestfold: Larvik, Jordstøyp i Kvelde, Ulmus glabra, 15.IX.2016 Spirin 11094*, 11102*, 11108*(O), 30.IX.2018 Spirin 12537 (O). Akershus: Asker, Esvika, rotten wood, 30.IX.2017 Larsson 17664* (O), U. glabra, 30.IX.2017 Spirin 11671*(O), Stokkerelva at Åstaddammen, U. glabra, 28.IX.2018 Spirin 12434 (O), rotten wood, 28.IX.2018 Larsson 17876 (O). Oslo. Bygdøy, Dronningberget, rotten wood, 30.IX.2017 Larsson 17673 (O). Buskerud: Lier, Stokkerinden, U. glabra, 29.IX.2018 Spirin 12492* (holotype, see below), Spirin 12482, 12494 (O), Fraxinus excelsior, 29.IX.2018 Spirin 12485 (O). Hedmark: Stange, Rotlia, F. excelsior, 26.IX.2018 Spirin 12422, 12425*(O), rotten wood, 26.IX.2018 Larsson 17834 (O). Oppland: NordFron, Liadalane Nat. Res., Alnus incana, 12.IX.2016 Spirin 11045* (O), Spirin 11052 (O), 29.IX.2017 Spirin $11641 *(O)$, Betula pubescens, 12.IX.2016 Spirin 11053* (O). Sogn og Fjordane: Luster, Loi, hardwood, 8.IX.2000 Roberts (O F146398). Møre og Romsdal: Nesset, Eikesdalen, U. glabra, 11.X.2011 B. Nordén 14-5663 (O F251651), 27.IX.2017 Spirin 11588*, 11589, 11599, 11604 (O), 11590, 11591 (infected by Achroomyces arachidispora) (O), 28.IX.2017 Spirin 11632 (O); Sunndal, Knutsliøyan, U. glabra, 15.IX.2014 Svantesson (O F75904). Ukraine. Kharkov Reg.: Izyum Dist., Spivakivka, A. glutinosa, 6.XI.2010 Akulov \& Ordynets (CWU 5998*).
Protomerulius microsporus. Mexico. Veracruz: Córdoba, Motzorongo, 15.I.1910 Murrill 990 (NY 00738344, holotype), Murrill 995 (NY 00738343, paratype); Barranca de Pescado, hardwood, 26.IX.1985 Ryvarden 23440* (O).

Protomerulius minor. Brazil. Pernambuco: Jaqueira, Frei Caneca, hardwood, 19.IV.2013 Larsson 15937* (O, epitype of Stypella minor). USA. Arkansas: Marion Co., Buffalo Point, hardwood, 25.X.2013 Miettinen 17461* (H). Massachusetts: Worcester Co., Worcester, Acer?, 1.XI.2014 Miettinen 19093.1 (H). New York: Catlin Co., Arbutus Lake, hardwood, 14.VIII.2012 Miettinen 15492* (H), Rich lake, fallen Acer?, 18.VIII.2012 Miettinen 15700* (H). Tennessee: Sevier Co., Gatlinburg, Ramsey Cascades trail, decayed wood, 13.VII.2004 Larsson 12173, 12185 (GB), Tilia americana, 30.IX.2015 Miettinen 19584.6, 19586* (H). Virginia: Alleghany Co., George Washington Nat. Forest, 5.IX.1940 Martin 5096 (NY 00738341).

Protomerulius pertusus. Norway. Møre og Romsdal: Nesset, Eikesdalen, Ulmus glabra, 16.IX.2014 Svantesson (O F75913*, holotype), decayed wood, 28.IX.2017 Larsson 17572* (O). Russia. Nizhny Novgorod Reg.: Lukoyanov Dist., Sanki, Quercus robur, 19-21.VIII.2009 Spirin 3081*, $3149^{*}(\mathrm{H})$, Corylus avellana, 21.VII.2018 Spirin $11947^{*}(\mathrm{H})$.

Protomerulius subreflexus. Indonesia. Papua: Sentani, Cycloop, fallen hardwood branch, 26.VIII.2004 Miettinen 9144 (MAN, H). Papua Barat: Manokwari, Saukorem, Ficus snag, 2.IX.2010 Miettinen 14339, fallen Artocarpus branch, 3.XI.2010 Miettinen 14392, fallen hardwood branch, 4.XI.2010 Miettinen 14402.1* (MAN, H). Riau: Siak, Beruk $\mathrm{N}$ field, fallen hardwood branch, 9.IV.2002 Miettinen 5642* (BO, H). Sumatera Barat: Sijunjung, Bukit Sebelah, fallen hardwood branch, 22.VII.2009 Miettinen 13695* (ANDA, H). Philippines. Luzon (lectotype of Polystictus subreflexus, see below).

Protomerulius substuppeus. Argentina. Missiones: Iguazu Nat. Park, hardwood, 1.III.1982 Ryvarden 19711 $(\mathrm{O}, \mathrm{H})$. Brazil. Paraná: Curitiba, Colégio Medianeira, hardwood, 13.V.1989 de Meijer 1247 (O, H). Santa Catarina: Blumenau, Jacaratia dodecaphylla (recently fallen branches), 1891-1893 Möller 23 (HBG, lectotype of P. brasiliensis), Möller 91 (HBG, as P. brasiliensis); without exact locality, 1874, Trail 123 (lectotype of Polyporus substuppeus, see below). Costa Rica. Alajuela: Carara Nat. Park, hardwood, 26-27.VII.2014 Vlasák 1407/20,1407/38*, 1407/41 (H, JV). Guanacaste: Río Tempisque, hardwood, 31.VII.2014 Vlasák 1407/104* (H, JV); Santa Rosa, hardwood, 18.X.1996 Lindblad 2105-B (O, H), 1.VII.1997 Lindblad 3269-A* (O F19171, H). Puntarenas: Monteverde, Santa Elena, 29.VII.2014 Vlasák 1407/53 (H, JV). Jamaica. Trewlany: Windsor Cave, dead wood, 12.VI.1999 Ryvarden 41683* (O, H). Puerto Rico. San Sebastián: Guajataca State Forest, hardwood, 26.VI.1996 
Ryvarden 39093* (O, H). Uganda. Kabarole: Kibale Forest Nat. Park, rotten log, 9.IX.2002 Ipulet F483* $(\mathrm{O}, \mathrm{H})$. USA. US Virgin Islands: St. John, hardwood, IX.2004 Vlasák 0409/10 (JV).

Psilochaete multifora. Norway. Møre og Romsdal: Nesset, Eikesdalen, U. glabra, 27.IX.2017 Spirin 11596* (O, holotype).

Acknowledgments The curators of herbaria TAAM, TRTC, NY, K, BPI, URC, LE, GB, and CWU are thanked for providing specimens for loan. Author VS is grateful to Mattias Schultz (University of Hamburg, Germany) and Bart Buyck (The French National Museum of Natural History) for arranging his visits to herbaria HBG and PC.

Funding information Open access funding provided by University of Helsinki including Helsinki University Central Hospital. The research was supported by Norwegian Biodiversity Information Centre (project "A survey of Norwegian jelly fungi," grant number knr. 44-15) (the authors VS and KHL), by Komarov Botanical Institute (project number AAAA-A19-119020890079-6, author VM), by CNPq (project number 307601/2015-3), FACEPE (project number APQ 0375-2.03/15) (authors TBG and RLMA), and CAPES (project number Capes-SIU 008/13) (authors TBG, KHL, and RLMA).

Open Access This article is distributed under the terms of the Creative Commons Attribution 4.0 International License (http:// creativecommons.org/licenses/by/4.0/), which permits unrestricted use, distribution, and reproduction in any medium, provided you give appropriate credit to the original author(s) and the source, provide a link to the Creative Commons license, and indicate if changes were made.

\section{References}

Alvarenga RLM, Spirin V, Malysheva V, Gibertoni TB, Larsson KH (2019) Two new genera and six other novelties in Heterochaete sensu lato (Auriculariales, Basidiomycota). Botany (accepted). https://doi.org/10.1139/cjb-2019-0046

Bandoni R, Oberwinkler F, Wells K (1982) On poroid genera of the Tremellaceae. Can J Bot 60:998-1003

Bourdot H, Galzin A (1909) Hyménomycètes de France: I. Heterobasidiés. Bull Soc Mycol France 25:15-36

Bourdot H, Galzin A (1928) Hyménomycètes de France. Hetérobasidiés - Homobasidiés gymnocarpes. Sceaux. pp 764

Burt EA (1924) Some wood-destroying fungi of Java. Ann Missouri Bot Gdn 11:37-42

Friedrichsen I (1977) Das Schicksal der von A. Möller in Brasilien (1890-1895) gesammelten Pilze sowie eine Liste der noch vorhandenden Sammlungsstücke. Mitt Inst Allgem Bot Hamburg 15:99-104

Gardes M, Bruns TD (1993) ITS primers with enhanced specificity for basidiomycetes application to the identification of mycorrhizae and rusts. Mol Ecol 2:132-118. https://doi.org/10.1111/j.1365-294x. 1993.tb00005.x

Kisimova-Horovitz L, Oberwinkler F, Gómez LDP (1997) Basidiomicetos resupinados de Costa Rica. Exidiaceae (Tremellales). Rev Biol Trop 45:1325-1347

Kumar S, Stecher G, Li M, Knyaz C, Tamura K (2018) MEGA X: Molecular Evolutionary Genetics Analysis across computing platforms. Mol Biol Evol 35:1547-1549. https://doi.org/10.1093/ molbev/msy096
Landvik S (1996) Neolecta, a fruit-body producing genus of the basal ascomycetes, as shown by SSU and LSU rDNA sequences. Mycol Res 100:199-202

Lowy B (1971) Tremellaceae. Flora Neotropica 6:1-153

Luck-Allen ER (1960) The genus Heterochaetella. Can J Bot 39:559569

Malysheva V, Spirin V (2017) Taxonomy and phylogeny of the Auriculariales (Agaricomycetes, Basidiomycota) with stereoid basidiocarps. Fungal Biol 121:689-715

Malysheva V, Spirin V, Miettinen O, Motato-Vásquez V, Hernawati SJSS, Larsson KH (2018) Revision of Protohydnum (Auriculariales, Basidiomycota). Mycol Prog 17:805-814

McNabb RFR (1969) New Zealand Tremellales - III. New Zealand J Bot 7:241-261

Miettinen O, Spirin V, Niemelä T (2012) Notes on the genus Aporpium (Auriculariales, Basidiomycota), with a new species from temperate Europe. Ann Bot Fennici 49:359-368

Miettinen O, Vlasák J, Rivoire B, Spirin V (2018) Postia caesia complex (Polyporales, Basidiomycota) in temperate northern hemisphere. Fungal Syst Evol 1:101-129

Möller A (1895) Protobasidiomyceten. Bot Mitth Tropen 8:1-180

Rambaut A, Drummond AJ, Xie D, Baele G, Suchard MA (2018) Posterior summarisation in Bayesian phylogenetics using tracer 1.7. Syst Biol 67(5): 901-904. https://doi:https://doi.org/10.1093/ sysbio/syy032

Rehner SA, Buckley E (2005) A Beauveria phylogeny inferred from nuclear ITS and EF1-a sequences: evidence for cryptic diversification and links to Cordyceps teleomorphs. Mycologia 97:84-98

Reid DA (1990) New or interesting records of British Heterobasidiomycetes. Mycol Res 94:94-108

Reid DA (1992) The genus Elmerina (Tremellales), with accounts of two species from Queensland, Australia. Persoonia 14:465-474

Roberts P (1998) A revision of the genera Heterochaetella, Myxarium, Protodontia, and Stypella (Heterobasidiomycetes). Mycotaxon 69: 209-248

Ronquist F, Teslenko M, van der Mark P et al (2012) MrBayes 3.2: efficient Bayesian phylogenetic inference and model choice across a large model space. Syst Biol 61(3):539-542. https://doi.org/10. 1093/sysbio/sys029

Ryvarden L (1991) Genera of polypores. Syn Fungorum 5:1-373

Ryvarden L (2016) Neotropical polypores. 3. Syn Fungorum 36: $446-613$

Setliff EC, Ryvarden L (1982) The genus Aporpium and two additional poroid fungi. Can J Bot 60:1004-1011

Sotome K, Maekawa N, Nakagiri A, Lee SS, Hattori T (2014) Taxonomic study of Asian species of poroid Auriculariales. Mycol Prog 13: 987-997

Spirin V, Malysheva V, Haelewaters D, Larsson KH (2019a) Studies in the Stypella vermiformis group. Antonie Van Leeuwenhoek 112: $753-764$

Spirin V, Malysheva V, Roberts P, Trichies G, Savchenko A, Larsson KH (2019b) A convolute diversity of the Auriculariales (Agaricomycetes, Basidiomycota) with sphaeropedunculate basidia. Nor J Bot 37(7): 1-26

Thiers B (2019) Index Herbariorum: a global directory of public herbaria and associated stuff [continuosly updated]. New York Botanical Garden's Virtual Herbarium. http://sweetgum. nybg.org/ih

Vilgalys R, Hester M (1990) Rapid genetic identification and mapping of enzymatically amplified ribosomal DNA from several Cryptococcus species. J Bacteriol 172:4239-4246

Vlasák J, Vlasák J Jr, Ryvarden L (2016) Studies in neotropical polypores. 42. Syn Fungorum 35:9-33 
Weiss M, Oberwinkler F (2001) Phylogenetic relationships in Auriculariales and related groups - hypotheses derived from nyclear ribosomal DNA sequences. Mycol Res 105:403-415

White TJ, Bruns T, Lee S, Taylor J (1990) Amplification and direct sequencing of fungal ribosomal RNA genes for phylogenetics. In: Innis MA, Gelfand DH, Sninsky JJ, White TJ (eds) PCR protocols: a guide to methods and applications. Academic Press, New York, pp 315-322
Zhou LW, Dai YC (2013) Phylogeny and taxonomy of poroid and lamellate genera in the Auriculariales (Basidiomycota). Mycologia 105: $1219-1230$

Publisher's note Springer Nature remains neutral with regard to jurisdictional claims in published maps and institutional affiliations. 